\title{
AÜS
}

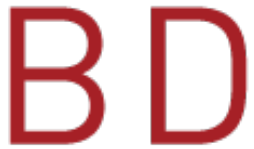

Anadolu Üniversitesi Sosyal Bilimler Dergisi

Anadolu University Journal of Social Sciences

\section{Türk Kamu Mali Yönetiminde İç Kontrol Sisteminin Belirleyicilerinin Araştırılması: Büyükşehir Belediyeleri Örneği ${ }^{1}$}

\author{
Durdane KÜÇÜKAYCAN² - Şafak AĞDENiZ
}

\section{Öz}

İ̧̧ kontrol sistemi, yeni kamu mali yönetiminin amaçlarının gerçekleştirmesinde kullanılan önemli araçlardan birisidir. 5018 sayıl Kanunun kapsamında yer alan kamu idarelerinin iç kontrol sistemlerini kurmaları gerekmektedir. Bu çalışmanın amacı büyükşehir belediyelerinin iç kontrol sistemlerinin etkinliğini belirleyen faktörlerin tespit edilmesidir. Çalışmada ilk olarak, içerik analizi yapılarak her bir büyükşehir belediyesi için iç kontrol sistemi performans puanı oluşturulmuş ve en yüksek başarı düzeyinden en düşük başarı düzeyine doğru belediyelerin sıralaması yapılmıştır. İkinci olarak ise, belediyelerin iç kontrol sisteminin etkinliğini belirleyen faktörler korelasyon analiziyle tespit edilmesine çalışılmıştır. Çalışmada kullanılan faktörlerden sadece belediye başkanının siyasi ideolojisi ile iç kontrol sistemi etkinliği arasında anlamlı bir sonuç bulunmuştur.

Anahtar Kelimeler: I̧ç Kontrol, Belediye, COSO, Sayıştay, Iç Denetim

Atıf: Küçükaycan, D. ve Ağdeniz, Ş. (2021). Türk kamu mali yönetiminde iç kontrol sisteminin belirleyicilerinin araştırılması: Büyükşehir belediyeleri örneği. Anadolu Üniversitesi Sosyal Bilimler Dergisi, 21(3), 827-850.

\footnotetext{
${ }^{1}$ Bu çalışma etik kurul izin belgesi gerektirmemektedir.

${ }^{2}$ Eskişehir Osmangazi Üniversitesi IİBF Maliye Bölümü, durdane@ogu.edu.tr, ORCID: 0000-0001-5515-2616

${ }^{3}$ Eskişehir Osmangazi Üniversitesi İ̈BF İşletme Bölümü, agdenizsafak@gmail.com, ORCID: 0000-0003-0373-4694
} 


\title{
Investigation of Determinants of Internal Control System in Turkish Public Fiscal Management: Case of Metropolitan Municipalities
}

\author{
Durdane KÜÇÜKAYCAN ${ }^{4}$ - Şafak AĞDENiZ ${ }^{5}$
}

\begin{abstract}
The internal control system is one of the important tools used in the realization of the objectives of the new public fiscal management. Public administrations within the scope of Law No. 5018 are required to establish internal control systems. The aim of this study is to determine the factors that determine the effectiveness of the internal control systems of metropolitan municipalities. In the study, firstly, the internal control system performance score was created for each metropolitan municipality by making content analysis and the municipalities were ranked from the highest success level to the lowest success level. Secondly, the factors that determine the effectiveness of the internal control system of the municipalities were tried to be determined by correlation analysis. Among the factors used in the study, a significant result was found only between the political ideology of the mayor and the effectiveness of the internal control system.
\end{abstract}

Keywords: Internal Control, Municipality, COSO, Court of Accounts, Internal Audit

\footnotetext{
${ }^{4}$ Eskisehir Osmangazi University, Faculty of Economics and Administrative Sciences, Department of Public Finance, durdane@ogu.edu.tr, ORCID: 0000-0001-5515-2616

${ }^{5}$ Eskisehir Osmangazi University, Faculty of Economics and Administrative Sciences, Department of Business Administration, agdenizsafak@gmail.com, ORCID: 0000-0003-0373-4694
} 


\section{Giriş}

Kamu mali yönetiminde yaşanan aksaklıklar ve sorunlar ile küreselleşme, Türkiye'de kamu mali yönetimini yeniden şekillendirmiştir. Kamu mali yönetimi reformu, 10.12.2003 tarihli ve 5018 sayılı Kamu Mali Yönetimi ve Kontrol Kanunu (KMYKK) ile gerçekleştirilmiştir. Söz konusu kanun ile kamu mali yönetimi, uluslararası standartlarla ve mevzuata uygun hale getirilmiştir. Kanunda iç kontrol ve iç denetim birimlerinin kurularak yeni kamu mali yönetiminin unsurları olan şeffaflık ve hesap verebilirliğin arttırılması amaçlanmıştır. Kamu idarelerinde oluşturulan iç kontrol sistemleri için temel düzenleme olan İç Kontrol Standartları Tebliği, The Committee of Sponsoring Organization (COSO) İç Kontrol Çerçevesi esas alınarak oluşturulmuştur.

Kamu idareleri iç kontrol sistemlerini kurmakla sorumludur. İç kontrol sisteminden beklenen faydaların sağlanması için ise iç kontrolün tüm unsurları ile idarelerde uygulanması gerekmektedir. Bu kapsamda, kamuda iç kontrol sisteminin değerlendirmesi iç denetim birimleri ve Sayıştay tarafından yapılan denetimlerle gerçekleştirilmektedir. İç denetim birimleri iç kontrol sisteminin bir parçası olarak iç kontrol faaliyetlerini izleme görevini yerine getirmek için kurulmuştur. Bununla birlikte 6085 sayılı Sayıştay Kanunu gereği Sayıştay tarafından da iç kontrol sistemlerinin etkinliği, düzenlilik denetimleri aracıllğıyla değerlendirilmektedir. Söz konusu bu değerlendirmeler kapsamında Sayıştay tarafından 2020 yllında "Kamuda Stratejik Yönetim Kurumsal Risk Yönetimi ve İç Kontrol Sistemi” başlıklı çalışma yayınlanmıştır. Çalışmada kamu idarelerinde iç kontrol sistemlerinin kurulup kurulmadığı ve bu sistemlerin etkin çalışıp çalışmadığ değerlendirilmektedir (Sayıştay, 2020, s. 8).

Belediyelerin iç kontrol sistemlerinin etkinliğinin iyileştirilmesi, daha iyi bir mali yönetimi sağlayacaktır (Fourie ve Ackermann, 2013, s. 496). Kamu mali yönetiminin belirlenen amaçlara ulaşması için kurulan yeni sistemin önemli bir ayağı olan iç kontrol sisteminin etkin bir şekilde işlemesi gerekmektedir. Bu kapsamda çalışmanın ana amacı Türkiye'de belediyelerin iç kontrol sistemlerinin etkinliğini belirleyen faktörlerin neler olduğunun belirlenmesidir. Bu amaç doğrultusunda ilk olarak Sayıştay tarafından yapılan düzenlilik denetimlerinde iç kontrol değerlendirmesine ilişkin ölçek ve sorular esas alınarak belediyelerin iç kontrol sistemleri içerik analizi ile değerlendirilecektir. İkinci adımda ise belediyelerin iç kontrol sistem kalitesini etkileyen faktörler korelasyon analizi kullanılarak belirlenmeye çalışllacaktır. Çalışmadan elde edilen bulguların kamuda iç kontrol sistemini etkileyen faktörlerin tespiti alanında hem akademik hem de uygulama alanında önemli katkılar sağlayacağı düşünülmektedir.

Bu kapsamda çalışmanın ilk bölümünde iç kontrol sisteminin kalitesini etkileyen faktörlere ilişkin literatür taramasına yer verilecektir. İkinci bölümde ise iç kontrol ve belediyelerde iç kontrol sistemine ilişkin teorik altyapı sunulacaktır. Üçüncü bölümde çalışmanın uygulama bölümü yer almaktadır. Dördüncü bölümde ise çalışmadan elde edilen sonuçlar değerlendirilecektir.

\section{Literatür Taraması}

İç kontrol sisteminin etkinliğini belirleyemeye yönelik yapılan literatür taramasında çalışmaların iki alanda yoğunlaştığı görülmektedir. Bu alanlardan ilki iç kontrol sisteminin zayıflıklarını belirlemede etkili olan faktörlerin ele alındığı çalışmalardan oluşmaktadır. Liang, Lourie ve Yeung (2019) cinsiyetin iç kontrol kalitesi üzerine etkilerini ele aldıkları çalışmalarında kadın muhasebeci sayısı ile iç kontrol zayıflıkları arasında ters yönlü bir ilişki tespit etmişlerdir. Aynı yönde bir cinsiyet çalışması da Chen, Eshleman ve Soileau (2016) tarafından yapılmıştır. Yazarlar çalışmalarında yönetim kurulundaki kadın sayısı ile iç kontrol sistemi zayıflıkları arasında ters yönlü bir ilişki tespit etmişlerdir. Doyle, Ge ve McWay (2007) 779 işletme üzerinde yaptıkları çalışmada, iç kontroldeki maddi zayıflıkların daha küçük, daha az kârlı, daha karmaşık, hızlı büyüyen veya yeniden yapılanma sürecinden geçen firmalar için daha muhtemel olduğunu ortaya koymuşlardır. 
Literatürdeki diğer alan ise iç kontrol kalitesini etkileyen unsurları inceleyen çalışmalardan oluşmaktadır. Oissuii ve Taktak (2018) iç denetim faaliyetinin iç kontrol sistemi kalitesi üzerine etkilerini Tunus'ta faaliyet gösteren 59 işletmede incelemişlerdir. Yazarlar regresyon analizi yaptıkları çalışmalarında iç denetim faaliyetinin ve iç denetçi niteliklerinin iç kontrol kalitesiyle olumlu ve önemli ölçüde ilişkili olduğunu dair bulgular elde etmişlerdir. Chang ve diğerleri (2019) Tayvan'da yaptıkları çalışmada iç denetçi sayısının iç denetim faaliyetinin performansını arttırdığını ve iç denetçi nitelikleri ile iç kontrol sisteminin etkinliği arasında pozitif bir ilişki olduğunu tespit etmişlerdir. Shen ve diğerleri (2021) iç kontrol kalitesini belirleyen unsurlara ilişkin çalışmalarını Çin'de borsaya kayıtlı işletmelerde incelemişlerdir. Çalışmada kırsal kökene sahip CEO’nun işletmenin iç kontrol kalitesini önemli ölçüde arttırabileceği bulunmuştur. Ayrıca CEO kadın olduğunda kökenin iç kontrol üzerinde çok belirgin bir öneminin olmadığı; CEO yaşlı ve yüksek eğitim düzeyine sahip olduğunda kırsal kökenin iç kontrol kalitesi üzerindeki etkisinin daha belirgin olduğu tespit edilen diğer başlıklardır. Xu ve Gao (2015) çalışmalarında kurumsal yönetimin işlevleri olan sahiplik yapısı, yönetim ve denetim kurulu toplantı sayısı, bağımsız yönetici ve makam tazminatı ile iç kontrol etkinliğini incelemişlerdir. Makam tazminatı ile yönetim ve denetim kurulu toplantı sayısı ile iç kontrol etkinliği arasında pozitif bir ilişki tespit edilmiştir. Lartey ve diğerleri (2020) kamu kurumlarının iç kontrol sistemine uyumlarını 395 ankete dayanarak inceledikleri ve yapısal eşitlik modelini kullandıkları çalışmalarında önleyici tedbirler uygulayan işletmelerin iç kontrol sistemlerinin daha etkili olduğunu belirlemişlerdir. Fourie ve Ackermann (2013) tarafından yapılan çalışmada iç denetçilerin COSO bileşenlerinin iç kontrolün etkililiği üzerindeki önemini ve etkisini nasıl algıladıkları anket kullanılarak araştırılmıştır. Yazarlar, iç denetçilerin COSO çerçevesinin risk değerlendirme, bilgi ve iletişim, izleme ve kontrol faaliyetleri unsurlarının, eğer uygulanırsa, iç kontrol sistemlerinin etkinliğini artırmada katkıda bulunan bir faktör olarak algıladıkları tespit edilmiştir.

Rae ve Subramaniam (2008) çalışmalarında iç kontrol üzerinde kurumsal etik ortamı, iç denetim faaliyeti ve risk yönetimi eğitiminin etkilerini çoklu regresyon analizi kullanarak analiz etmişlerdir. Verilerin anket ile toplandığı çalışmada her üç faktörün iç kontrolün kalitesini arttırdığı tespit edilmiştir. Hung ve Tuan (2019) bankacılık sektöründe iç denetimin etkinliğine etki eden faktörleri kısmi regresyon analizi ile inceledikleri çalışmalarında yedi değişken kullanmışlardır. Kontrol ortamı, kontrol eylemleri, izleme, risk değerlendirme, bilgi ve iletişim, banka büyüklügü ve kredi durum sıralaması (credit status ranking) değişkenlerinin hepsinin iç kontrol etkinliği ile arasında pozitif bir ilişki tespit edilmiştir. İç kontrol üzerine etkinliği en fazla olan değişken ise kontrol ortamı olarak bulunmuştur. Hunziker (2017) çalışmasında 254 CFO ve CEO ile anket yaparak verileri toplamış ve yapısal eşitlik modeli kullanarak ilk olarak iç kontrol etkinliğini ortaya koymaya çalışmıştır. İç kontrol etkinliğini belirlemede hedef yaklaşımı, sistem yaklaşımı ve süreç yaklaşımı altında toplamda 5 unsur kullanılmıştır. Bu unsurlar; hedefe ulaşılma derecesi, koordinasyon etkinliği, işletme esnekliği, kaynak kullanımı ve girdi çıktı oranıdır. Sonrasında ise azaltılmış karmaşıklık, yetkinlik, iç iletişim ve izleme faktörlerinin iç kontrol etkinliği üzerine etkileri incelenmiş ve dört faktörün de iç kontrolün etkinliğini arttıran belirleyiciler olduğu tespit edilmiştir.

Ulusal literatürde ise kamu idarelerinin iç kontrol sistemlerinin değerlendirilmesine ilişkin çok fazla bir çalışmaya rastlanılmamıştır. Ağmaz (2017) çalışmasında Türkiye'deki belediyelerin iç kontrol sistemlerinin etkinliğini Sayıştay tarafından yapılan düzenlilik denetimlerini inceleyerek genel bir değerlendirmede bulunmuştur. Belediyelerin iç kontrol sistemlerinde özellikle uygulamaya yönelik eksiklikler olduğunu belirtmiştir. Bu eksikliklerin ana başlıklarından bazıları üst yönetimin iç kontrol sistemini desteklememesi, iç denetim birimlerinin kurulmasının ve idare tarafından yeterince desteklenmemesi ve bu birimler kurulsa dahi nitelikli personel istihdam edilmemesidir. Çevik ve Ağmaz (2019) Türkiye'de Büyükşehir belediyelerinin İç Kontrol Eylem Planlarını analiz ederek, belediyelerin Kamu İç Kontrol Standartlarına uyumlarını analiz etmişlerdir. Yazarlar, büyükşehir belediyelerinin iç kontrol sistemlerinin henüz kamu iç kontrol standartları ile tam olarak uyumlu olmadığını özellikle risk değerlendirme ve kontrol faaliyetleri bileşenlerinin geliştirilmesi gerektiği sonucuna varmışlardır. 
$\mathrm{Bu}$ çalışmanın uluslararası literatürde yapılan çalışmalarda Hunziker (2015) tarafından yapılan çalışma ile benzer olduğu görülmekle birlikte önemli farklılıkları söz konusudur. Öncelikle çalışmada kamu sektörü ele alınmakta ve iç kontrol değerlendirmesi geniş bir iç kontrol çerçevesi ele alınarak değerlendirilmektedir. İç kontrol etkinliğini belirlemede ise yine literatürde yapılan çalışmaların değişkenlerine ek olarak değişkenler yer almaktadır. Dolayısıyla bu çalışma kapsamı ve amacı ile kamu sektöründe yapılmış literatürdeki ilk çalışmalardan biri olacaktır. Bu çalışmada öncelikle belediyelerin iç kontrol sistemlerinin kalitesi içerik analizi ile tespit edilecek, sonrasında kaliteli iç kontrol sistem olan belediyelerin iç kontrol sistem kalitesini etkileyen unsurlar tespit edilmeye çalışılacaktır. Çalışmanın kamuda iç kontrol sisteminin belirleyicilerine ilişkin literatürdeki boşluğu tamamlayarak literatüre ve uygulamacılara önemli katkılar sağlaması beklenmektedir.

\section{Kavramsal Çerçeve}

\section{İç Kontrol Kavramı}

Küresel anlamda iç kontrol ve iç denetim hem kamu hem de özel sektör için yeni kontrol ve yönetişim çerçevelerinin ortaya çıkmasıyla birlikte bir dönüşüm sürecinden geçmektedir. Bu çerçevelerin birçoğu, kamu ve özel kuruluşları güçlü bir iç kontrol ve iç denetim fonksiyonları oluşturmaya zorlamaktadır (Lartey vd., 2020, s. 712). İç kontrol, işletme faaliyetlerinin etkinliği ve verimliliğinin, mali raporlamanın güvenilirliğinin, yasa ve mevzuata uyumun sağlanması için makul güvence vermek üzere tasarlanan, kurumun yönetim kurulu, yönetimi ve çalışanları tarafından etkilenen bir süreçtir (COSO, 2013, s. 13). Özellikle Dünya'da yaşanan finansal skandallar sonucunda menfaat sahiplerinin güvenini yeniden teşkil etmek ve krizlerin ekonomik etkilerinin azaltılması amacıyla iç kontrol kavramı önem kazanan bir alan olmuştur.

Etkili bir iç kontrol sistemi, işletmenin yönetişim sisteminin ve riski yönetme becerisinin önemli bir bileşeni olarak işletmenin hedeflerine ulaşılmasını desteklemekte, paydaş değerini geliştirmekte ve korumaktadır (Moeller, 2013, s. 2).

Dünya'da geliştirilmiş CoCo, ESAC, COBIT, Turnbill Raporu gibi birçok iç kontrol çerçevesi mevcuttur. Ancak bu iç kontrol çerçeveleri COSO iç kontrol çerçevesi kadar kapsamlı olmadığından, COSO iç kontrol çerçevesi tüm dünyada en çok bilinen ve uygulanan çerçeve olarak karşımıza çıkmaktadır (Graham, 2015, s. 2). COSO (Committe of Sponsoring Organizations of the Treadway - Treadway Komisyonunu Destekleyen Kuruluşlar Komitesi) 1985 yllında hileli finansal raporlamanın önlenmesi, iç kontrol, risk yönetimi, kurumsal yönetim gibi alanlarda kapsamlı rehber hazırlamak amacıyla Amerikan Sertifikalı Kamu Muhasebecileri Enstitüsü (AICPA), Amerikan Muhasebe Birliği (AAA), Finansal Yöneticiler Enstitüsü (FEI), İç Denetçiler Enstitüsü (IIA) ve Yönetim Muhasebecileri Enstitüsü (IMA) tarafında kurulmuş bir organizasyondur.

COSO, iç kontrol rehberi olarak 1992 yllında İç Kontrol Bütünleşik Çerçeveyi yayınlamış ve yaşanan gelişmelere paralel olarak söz konusu çerçeve 2013 yılında güncellenmiştir. COSO iç kontrol çerçevesinin kontrol çevresi, risk değerleme, kontrol eylemleri, bilgi ve iletişim ile izleme faaliyeti olmak üzere beş unsuru vardır. Bu beş unsur bütüncül bir yapı içinde birbiri ile ilişkilidir ve birbirlerini etkilemektedir (Graham, 2015, s. 3) ve ilk çerçevede de aynı şekilde yer almaktadır. Güncelleme ile birlikte getirilen en önemli yenilik bu beş unsurun altından toplamda 17 ilkenin ve ayrıca odak noktalarının belirlenmiş olmasıdır. Yeni çerçevede ilkelerin bu kadar fazla olmasının en önemli nedeni iç kontrol çerçevesinin kâr amacı güden ya da gütmeyen, halka açık, özel ya da kamu kurumları ve diğer tüm kuruluşlarda uygulanabilirliğinin sağlanmasıdır (Moeller, 2013, s. 37).

Kontrol çevresi, çalışanlarda iç kontrol bilincinin oluşturulmasını sağlayarak diğer iç kontrol unsurlarının temelini oluşturur (Moeller, 2013, s. 42; Graham, 2015, s. 99). Etkili bir kontrol ortamı, kurumun hedeflerine ulaşması, kontrol faaliyetlerinin gerçekleştirilmesi ve bilgi ve iletişim sistemlerinin kullanımı ile izleme 
faaliyetlerinin yürütülmesi için gerekli risklerin değerlendirilmesini destekleyen disiplini oluşturur. Kontrol çevresi için COSO'da belirtilen ilkeler; dürüstlük ve etik değerlere bağlllık, yönetim kurulunun gözetim sorumluluğu, yetki ve sorumlulukların belirlenmesi, yetkinlik ve hesap verebilirliktir. Bir işletmenin iç kontrol ortamı, iç kontrol kültürü olarak görülebilir. Dürüstlük ve etik değerler, gözetim, hesap verebilirlik ve performans değerlendirmeleri gibi güçlü bir kültürün unsurları, kontrol ortamını da güçlü kılar (Moeller, 2013, s. 42). Risk değerleme, yönetimin riskleri nasıl yönetebileceği konusunda bir esas oluşturmak üzere, hedeflere ulaşmada ortaya çıkabilecek risklerin belirlenmesi ve analiz edilmesi sürecidir (Yılanc1, 2015, s. 93). Bu unsur için dört ilke belirlenmiştir. Bu ilkeler; hedeflerin belirlenmesi, risklerin belirlenmesi ve analizi, hile risklerinin değerlendirilmesi ve önemli değişikliklerin belirlenmesi analiz edilmesidir. Kontrol eylemleri; işletmenin hedeflere ulaşılmasına yönelik risklerin yönetilmesinde uygulanacak yöntem ve politikalar aracılığıyla oluşturulan eylemler olup işletmenin her kademesinde, iş birimleri ve süreçler içerisinde çeşitli aşamalarda ve teknoloji ortamında gerçekleştirilen kontrol faaliyetleridir (Moeller, 2013, s. 73).

Kontrol eylemleri unsuruna ait ilkeler; kontrol faaliyetlerinin belirlenmesi ve seçilmesi, teknoloji üzerindeki genel kontrollerin belirlenmesi ve geliştirilmesi ile kontrol faaliyetlerine ilişkin politika ve prosedürlerin oluşturulmasıdır. Bilgi ve iletişim unsurunda iç kontrolün amaçlarına ulaşmasında oluşturulan politika ve prosedürlerin çalışanlara aktarılması amaçlanır. Bilgi ve iletişim işletmenin amaçlarına ulaşmasına sağlayan iç kontrol faaliyetlerinin yerine getirilmesi için gerekli ve diğer iç kontrol unsurlarını destekleyen bir unsurdur (Moeller, 2013, s. 87). Doğru ve ilgili bilgi paylaşımının ve iletişimin zamanında yapılması gerekir. Çerçevede, bilgi ve iletişim unsurunun ilgili/kaliteli bilginin kullanılması, iç iletişimin sağlanması ve dış iletişimin sağlanması olmak üzere üç ilkesi tanımlanmıştır. İzleme unsuru, iç kontrol sisteminin değerlendirilmesi ve etkinliğinin sağlanmasıdır (Graham, 2015, s. 173). Revize edilmiş iç kontrol çerçevesinde temel bir hedef olan izleme, devam eden, ayrı veya bu iki değerlendirmenin birlikte kullanılarak ilk dört iç kontrol unsurunun işletmede olup olmadığının ve nasıl işlediğinin değerlendirilmesi sürecidir (Moeller, 2013, s. 105). Devamlı ve özel değerlendirmelerin yapılması ile eksikliklerin giderilmesi ve ilgili taraflara bilgi verilmesi izleme unsurunun belirlenen iki bileşenidir.

Türkiye'de de Dünya'daki gelişmelere paralel olarak iç kontrol alanında birçok gelişme yaşanmış ve iç kontrol alanında yasal düzenlemeler yapılmıştır. İç kontrole ilişkin düzenleme yapan kurumlar aşağıda verilmiştir (Ağdeniz, 2019, s. 93):

- Sermaye Piyasası kurulu tarafından yapılan düzenlemeler,

- Bankacilık Düzenleme ve Denetleme Kurulu tarafından yapılan düzenlemeler,

- 5018 Sayılı KMYKK ile yapılan düzenlemeler,

- 6102 Sayılı Türk Ticaret Kanunu ile yapılan düzenlemeler.

\section{Kamu Mali Yönetimi ve Belediyelerde İç Kontrol}

Türkiye'de belediyeler genel yönetim kapsamında yer alan mahalli idareler olarak sınıflandırılmıştır. Bu nedenle belediyelerin tüm mali işlemlerinin temel yasal dayanağını 5018 sayılı KMYKK oluşturmaktadır. 5018 Sayılı KMYKK, kamu mali yönetiminin eksikliklerini gidermek ve uluslararası düzenlemelerle uyumlu olabilmek adına yapılan kamu mali reformunun gerçekleşmesini sağlayan temel yasal düzenlemedir. Söz konusu kanunun ana amaçları hesap verebilirlik ve şeffaflık olarak belirtilmiş ve bu amaçları gerçekleştirebilmek için kanunla yeni düzenlemeler yapılmıştır. İç kontrol sisteminin oluşturulması ve iç denetim birimlerinin kurulması bu yeni düzenlemelerden ikisidir. İç kontrol 5018 sayılı Kanunun 55. maddesinde düzenlenmiş ve tanımlanmıştır. Her bir kamu idaresi bünyesinde iç kontrol sistemi kurmak ve bu 
sistemin etkin olarak işleyişinden sorumludur 6018 sayılı Kanunun 56. maddesinde de iç kontrol sisteminin amaçlarına yer verilmiştir. 5018 sayılı kanun dışında kamu idarelerinde iç kontrole ilişkin yasal düzenlemeler de yapılmıştır. Bu düzenlemeler aşağıda verilmiştir:

- İç Kontrol ve Ön Mali Kontrole İlişkin Usul ve Esaslar,

- 26.12.2007 tarih ve 26738 sayılı Resmî Gazete’de yayınlanan Kamu İç Kontrol Standartları Tebliği,

- Kamu İç Kontrol Standartlarına Uyum Eylem Planı Rehberi.

İç Kontrol ve Ön Mali Kontrole İlişkin Usul ve Esasları düzenleyen yönetmelik ile Kamu İç Kontrol Standartları Tebliği gibi düzenlemelerin Uluslararası Sayıştaylar Birliği (International Organization of Supreme Audit Institutions- INTOSAI) Kamu Sektörü İç Kontrol Standartları Rehberi ve diğer uluslararası genel kabul görmüş metinlerden alınmış olduğu anlaşılmaktadır (Akyel, 2010, s. 91). Ayrıca, bu yasal düzenlemelere ve Kamu İç Kontrol Standartları'nın uygulanması konusunda rehberlik sağlamak amacıyla 2014 yilında Kamu İç Kontrol Rehberi yayımlanmıştır.

Kamu İç Kontrol Standartlarına Uyum Eylem Planı Rehberinde, kamu idarelerinin dikkate almaları gereken yöntem ve ilkeler belirtilmiştir. Kamu İç Kontrol Standartları, uluslararası kuruluşların düzenlemelerine uygun olarak 18 standart ve 79 genel şarttan oluşmaktadır. Kamu İç Kontrol Standartları Tablo 1'de verilmiştir.

Tablo 1

Kamu İç Kontrol Standartları

\begin{tabular}{lll}
\hline \multirow{2}{*}{ Kontrol Ortamı Standartları } & Standart 1 & Etik Değerler ve Dürüstlük \\
& Standart 2 & Misyon, organizasyon yapısı ve görevler \\
& Standart 3 & Personelin yeterliliği ve performansı \\
& Standart 4 & Yetki Devri \\
\hline Risk Değerlendirme Standartları & Standart 5 & Planlama ve Programlama \\
& Standart 6 & Risklerin belirlenmesi ve değerlendirilmesi \\
\hline & Standart 7 & Kontrol stratejileri ve yöntemleri \\
& Standart 8 & Prosedürlerin belirlenmesi ve belgelendirilmesi \\
Kontrol Faaliyetleri Standartları & Standart 9 & Görevler ayrılığı \\
& Standart 10 & Hiyerarşik kontroller \\
& Standart 11 & Faaliyetlerin sürekliliği \\
& Standart 12 & Bilgi sistemleri kontrolleri \\
\hline & Standart 13 & Bilgi ve iletişim \\
& Standart 14 & Raporlama \\
& Standart 15 & Kayıt ve dosyalama sistemi \\
& Standart 16 & Hata, usulsüzlük ve yolsuzlukların bildirilmesi \\
\hline \multirow{2}{*}{ Bilgi ve iletişim Standartları } & Standart 17 & İç kontrolün değerlendirilmesi \\
& Standart 18 & İç denetim \\
\hline İzleme Standartları &
\end{tabular}

Kaynak: Kamu İç Kontrol Standartları Tebliği'nden uyarlanmıştır.

Tablo 1'de verilen standartların COSO iç kontrol çerçevesi ile uyumlu olduğu görülmektedir. 5018 sayılı Kanunun 11. maddesine göre üst yöneticiler kamu idarelerinde iç kontrol sistemlerinin işleyişinin gözetilmesi, izlenmesi ve Kanunda belirtilen görev ve sorumlulukların yerine getirilmesinden sorumludurlar. Kanunda ayrıca bu sorumluluğun gereklerini, harcama yetkilileri, mali hizmetler birimi ve iç denetçiler aracılığıyla yerine getirileceği de belirtilmiştir. Bu kapsamda, belediyelerde, Strateji Geliştirme Daire Başkanlıkları veya

\footnotetext{
${ }^{6}$ Avrupa Birliğine üye ülkelerdeki yönetim kontrol sistemlerinde kuzey (Anglo-Sakson) ülkelerden İngiltere ve Hollanda'nın benimsediği ‘yönetim sorumluluğu (management responsibility) anlayışı'na göre, kamu iç mali kontrol sisteminin özellikle ex ante aşamasının, her bir kurumun kendi bünyesindeki kontrolörleri aracılığıyla yürütülmesi gerektiğine vurgu yapılmaktadır. İdarenin mali yönetim ve kontrol sistemine, idarenin dışından merkezi otoritelerce bir müdahalede bulunulmamaktadır. 5018 sayılı Kamu Mali Yönetimi ve Kontrol Kanunu ile bu model, Türkiye'de uygulanmaya başlanmıştır (Baykara, 2015, s. 47).
} 
aynı fonksiyonları yürüten Mali Hizmetler Birimleri, her türlü mali ve mali olmayan işlemlerinde bu standartlara uymak, bu standartların gereklerini yerine getirmek ve kendine ait iç kontrol sistemi oluşturmakla yükümlüdür (Yılmaz, 2019, s. 1).

Kamu idarelerinde kurulan iç kontrol sistemlerinin etkinliği iç denetim birimleri ve Sayıştay tarafından değerlendirilmektedir. İç denetim birimleri iç kontrolün izleme fonksiyonunun yerine getirilmesi kapsamında üst yöneticilere güvence ve danışmanlık hizmeti veren ve kamu idaresinde üst yönetime bağlı olarak kurulan birimlerdir. Sayıştay ise dış denetim ${ }^{7}$ kapsamında, 2012 yılından itibaren denetim raporlarında kamu idarelerinin iç kontrol sistemlerine ilişkin bulgulara yer vermektedir (Ağmaz, 2017, s. 75). Aynı zamanda Sayıştay 2018 yllından itibaren kamu idarelerinin stratejik yönetim, kurumsal risk yönetimi ve iç kontrolüne ilişkin çalışmalarını, yapmış olduğu anket çalışması ile analiz etmektedir. Çalışmada COSO iç kontrol modelinde yer alan 5 unsura göre bir sınıflandırma yapılmıştır. Bu kapsamda, Sayıştay 2020 yılında yayınlamış olduğu "Kamuda Stratejik Yönetim Kurumsal Risk Yönetimi ve İç Kontrol Sistemi” başlıklı çalışmada kamu idarelerinde iç kontrol sistemlerinin kurulup kurulmadığı ve bu sistemlerin etkin çalışıp çalışmadığına ilişkin yapmış olduğu analiz sonuçları yer almaktadır. Çalışmada soruların oluşturulmasında uluslararası standartlar dikkate alınmış olup bu standartlar aşağıda verilmiştir (Sayıştay, 2020, s. 8):

- COSO İç Kontrol-Bütünleşik Çerçeve,

- COSO Kurumsal Risk Yönetimi Çerçevesi,

- COSO İç Kontrol Bütünleşik Çerçeve- Bir İç Kontrol Sisteminin Etkililiğini Değerlendirmek İçin Kullanılabilecek Açıklayıcı Araçlar,

- COSO İç Kontrol-Bütünleşik Çerçeve-Dış Finansal Raporlama Üzerinde İç Kontrol: Bir Yaklaşımlar ve Örnekler Özeti,

- İç Kontrole İlişkin INTOSAI Rehberleri.

Sayıştay yukarıdaki standartları ve kamu mali yönetimindeki yasal yükümlülükleri de dikkate alarak 2018 yılına ait verileri 20 soruluk bir anket ile toplamış, 2019 yılında ise soru sayısını 35 'e çıkarmışıır'. Analizde yer alan 5 unsura ait 35 prosedürü Sayıştay değerlendirirken beş puanlı Likert Ölçeğini ${ }^{9}$ kullanmıştır. Analiz çalışmasında 445 kurumun stratejik yönetimleri ile kurumsal risk yönetimi ve iç kontrol sistemleri Sayıştay’ın 2019 yılı denetim sonuçları dikkate alınarak oluşturulmuştur. Analizde kamu idarelerini Sayıştay, bütçe türlerine göre ve 5018 sayılı Kanuna tabi olup olmadıklarına göre sınıflandırmıştır. Bütçe türlerine göre kamu idarelerinin stratejik yönetimi, kurumsal risk yönetimi ve iç kontrol sistemleri ayrı ayrı değerlendirilmiştir. Tablo 2'de 5018 sayılı Kanun'a tabi olan kurum ve kuruluşların iç kontrol sistemine ilişkin ortalama puanları yer almaktadir.

\footnotetext{
${ }^{7}$ Maliye Bakanlığı Strateji Geliştirme Başkanlığı İç Kontrol Dairesi tarafından oluşturulan İç Kontrol Kavramlar Sözlüğünde (2019, s. 7) dış denetim; mali raporlar ve muhasebe hesaplarının, operasyonların ve mali yönetimin yasallığı ve düzenliliği hakkında fikir vermek ve rapor hazırlamak amacıyla bağımsız ve kurum dışı bir organ tarafından yerine getirilen denetim olarak ifade edilmektedir.

8 Analizde kullanılan ankette yer alan prosedürlere ilişkin sorular Ek 1'de verilmiştir.

9 Ek 2'de yer alan ifadelere göre kamu idarelerine 0-4 puan aralığında puan verilerek idarelerin iç kontrol sistemlerinin kurulup kurulmadığ1 ve bu sistemlerin etkin çalışıp çalışmadığına ilişkin değerlendirme yapılmıştır.
} 
Tablo 2

5018 sayılı Kanun’a Tabi Olan Kurum ve Kuruluşların İç Kontrol Sistemleri Ortalama Puanları

\begin{tabular}{lcc}
\hline & Ortalama Puan (100 Puan Üzerinden) & \\
Bütçe Türü & & Kurum Sayısı \\
\hline Genel Bütçeli Kurumlar & 73 & 36 \\
Sosyal Güvenlik Kurumları & 71 & 2 \\
Özel Bütçeli İdareler B-Özel Bütçeli & 67 & 35 \\
Diğger İdareler & 66 & 98 \\
Özel Bütçeli İdareler A-Yükseköğretim & & \\
Kurulu, Üniversiteler ve Yüksek & & 160 \\
Teknoloji Enstitüleri & 62 & 331 \\
Mahalli İdareler & & \\
\hline Toplam Kurum Sayısı & & \\
\hline
\end{tabular}

Kaynak: Sayıştay (Kamuda Stratejik Yönetim Kurumsal Risk Yönetimi İç Kontrol Sistemi Analiz Çalışması), 2020 , s. 24.

Tablo 2'de bütçe türleri bakımından yapılan sınıflandırmaya göre iç kontrol sistemleri değerlendirildiğinde mahalli idarelerin en düşük (62) ortalamaya sahip olduğu görülmektedir. Sayıştay’ın yapmış olduğu çalışmada kamu idarelerinin iç kontrol sistemi için belirlenen puan ortalamaları kamu idarelerinin bütçe türlerine yönelik genel bilgiler verilmektedir. Her bir kamu idaresi için ayrı ayrı puanlamaya yer verilmemiştir. $\mathrm{Bu}$ çalışmada ise büyükşehir belediyelerinin iç kontrol sistemine ilişkin prosedürleri uygulayıp/uygulamadıkları her bir belediyenin denetim raporlarının ayrı ayrı incelenerek puanlanması yapılarak başarı düzeyi elde edilmiştir.

\section{Büyükşehir Belediyelerinin İç Kontrol Sisteminin Belirleyicilerinin Araştırılması}

Bu bölümde araştırmanın kapsamı, yöntemi ve verileri hakkında bilgiler verilerek araştırma bulguları değerlendirilmektedir.

\section{Araştırmanın Kapsamı, Varsayımları ve Kısıtları}

Araştırmanın evrenini Türkiye'deki 30 büyükşehir belediyesi oluşturmaktadır. Büyükşehir belediyeleri Türkiye'deki mahalli idareler arasında nüfus olarak ülkeyi temsil etme potansiyeli daha fazla olmakla birlikte büyük ölçekte hizmet üreterek şehrin tamamına hizmet sunmak için yüksek bütçeye ve daha fazla insan kaynağına sahiptir. İç kontrol sistemleri Sayıştay tarafından değerlendirildiğinde bütçe türleri bakımından yapılan sınıflandırmaya göre mahalli idareler en düşük ortalamaya sahiptir. 5018 sayılı Kanuna göre iç kontrol sisteminin etkin bir şekilde oluşturulması kamu idarelerinin sorumluluğunda olmakla birlikte, Sayıştay hem dış denetim sürecinin bir parçası olarak, hem de 6085 sayılı Sayıştay Kanunu ile verilen bir görev olarak iç kontrol sistemlerinin etkinliğini de değerlendirmektedir. Sayıştay tarafından gerçekleştirilen denetimler Kamu İdareleri Denetim Raporları aracılığıyla kamuoyu ile paylaşılmaktadır ve kamu idarelerinin 2019 yılına ait denetim sonuçları, 2020 yılında yayımlanmaktadır. Bu çalışmada, büyükşehir belediyelerinin Sayıştay tarafından hazırlanan 2019 Kamu İdareleri Denetim Raporları, "İç Kontrol Sistemi Değerlendirme Prosedürleri” esas alınarak analiz edilmiştir. Bu prosedürlerin belediye tarafından uygulanma/uygulanmama durumuna ilişkin bulgular, Sayıştay tarafından hazırlanan denetim raporunda, "iç kontrol sisteminin değerlendirilmesi” başlı̆̆ı altında yer almaktadır. 
Çalışmada belediyelerin iç kontrol sistemine ilişkin tarafsız ve sistematik bilgiye ulaşmak için bir araştırma yöntemi olan içerik analiziyle ${ }^{10}$ prosedürlerin uygulanma/uygulanmama durumuna göre puanlaması yapılmıştır. Sayıştay'ın 2020 yılında yapmış olduğu analiz çalışmasındaki ölçek dikkate alınarak ve benzer bir yöntem kullanılarak, denetim raporlarındaki sözel verilerin nicel hale dönüştürülmesi için büyükşehir belediyelerinin "İç Kontrol Sistemi Değerlendirme Prosedürlerinin" puanlaması yapılmıştır. Puanlama sonucunda her bir belediyeye ilişkin iç kontrol sistemlerinin etkinliği/etkisizliğine yönelik skorların elde edilmesi amaçlanmıştır. Çalışma, mevcut durumu betimlemeye yönelik bir çalışma olmakla birlikte birincil verilerin (büyükşehir belediyelerin performans denetim raporları) içerik analiziyle değerlendirilmesiyle ikincil veriler elde edilmiştir. Başka bir araştırmacının da araştırma kapsamında değerlendirilen denetim raporlarındaki bilgileri puanladığında benzer sıralamaya yakın bir sonucu elde edeceği öngörülmüştür. Ayrıca bazı büyükşehir belediyelerin Sayıştay denetim raporlarında "İç Kontrol Sistemi Değerlendirme Prosedürlerine" ilişkin herhangi bir bilgiye rastlanılmadığı durumlarda ilgi belediyenin bahse konu olan prosedürü yerine getirmediği varsayılmıştır.

\section{Araştırmanın Yöntemi}

35 prosedürü içeren "İç Kontrol Sistemi Değerlendirme Prosedürleri” 5 temel prosedür unsuruna sahiptir. Bunlar: Kontrol Ortamı (KOP-7 prosedür), Risk Değerlendirme (RDP-8 prosedür), Kontrol Faaliyetleri (KFP5 prosedür), Bilgi ve İletişim (BIP-6 prosedür) ile İzleme (IP-9 prosedür) Prosedürleridir. 5 temel prosedürü kendi içerisinde değerlendirebilmek için her bir prosedür (P harfi) olarak ifade edilmiştir. Örneğin Kontrol Ortamı Prosedürleri (KOP) olarak gösterilmiştir. Bu temel prosedüre kendi içerisinde 7 prosedüre sahip olduğu için her bir prosedür $\mathrm{KOP}_{1}, \mathrm{KOP}_{2}, \mathrm{KOP}_{3}, \mathrm{KOP}_{4}, \mathrm{KOP}_{5}, \mathrm{KOP}_{6}$ ve $\mathrm{KOP}_{7}$ olarak kısaltılmıştır. KOP'a ait 7 prosedürün biraya gelmesiyle ilgili belediyeye ait Kontrol Ortamı Prosedürü İçin Belediyenin Toplam Puanı $(\mathrm{KOP})_{\mathrm{j}}$ ulaşılmıştır.

Kontrol Ortamı Prosedürü İçin Belediyenin Toplam Puanı

Risk Değerlendirme Prosedürü İçin Belediyenin Toplam Puanı

Kontrol Faaliyetleri Prosedürü İçin Belediyenin Toplam Puanı

Bilgi ve İletişim Prosedürü İçin Belediyenin Toplam Puanı

İzleme Prosedürü İçin Belediyenin Toplam Puanı

$$
\begin{gathered}
\sum_{\mathrm{i}=1}^{7}(\mathrm{KOP}) \mathrm{i}=(\mathrm{KOP}) \mathrm{j} \\
\sum_{\mathrm{i}=1}^{8}(\mathrm{RDP}) \mathrm{i}=(\mathrm{RDP}) \mathrm{j} \\
\sum_{\mathrm{i}=1}^{5}(\mathrm{KFP}) \mathrm{i}=(\mathrm{KFP}) \mathrm{j} \\
\sum_{\mathrm{i}=1}^{6}(\mathrm{BIP}) \mathrm{i}=(\mathrm{BIP}) \mathrm{j} \\
\sum_{\mathrm{i}=1}^{9}(\mathrm{IP}) \mathrm{i}=(\mathrm{IP}) \mathrm{j}
\end{gathered}
$$

Yukarıdaki tüm hesaplamalar her bir büyükşehir belediyesi için ayrı ayrı yapılmıştır. Her bir belediyenin 5 temel prosedürün toplamından da büyükşehir belediyesinin İç Kontrol Sistemi Değerlendirme Prosedürlerinin (İKSDP) toplam puanına ulaşılmıştır.

$(K O P)_{j}+(R D P)_{j}+(K F P)_{j}+(B I P)_{j}+(I P)_{j}=(I K S S P)_{j}$ (Belediyenin İç Kontrol Sistemi Değerlendirme Prosedürleri Puani)

Denetim raporları incelenirken belediyelerin prosedürleri karşılama düzeyi içerik analiziyle değerlendirilerek beşli Likert Ölçeğine göre puanlaması yapılmıştır. Sayıştay tarafından yapılan çalışmada kullanılan puanlamanın örtüşmesi açısından beş puanlı ölçek tercih edilmiştir. Stratejik Yönetim, Kurumsal Risk Yönetimi ve İç Kontrol Sistemi Değerlendirme Prosedürlerine (Ek 1) göre belediyelere 0-4 puan aralığında

\footnotetext{
${ }^{10}$ Bir araştırma yöntemi olan içerik analizini, Krippendorff (1980, s. 21), veriden onun içeriğine ilişkin tekrarlanabilir ve geçerli sonuçlar çıkarmak için kullanılan bir araştırma tekniği olarak tanımlamaktadır.
} 
puan verilerek idarelerin iç kontrol sistemlerinin kurulup kurulmadığı ve bu sistemlerin etkin çalışıp çalışmadığına ilişkin değerlendirme yapılmıştır. İç Kontrol Sistemi Değerlendirme Prosedürleri 5 unsura ait 35 prosedürden oluşması bakımından prosedürleri etkin bir şekilde uygulayan belediyenin maksimum 140 puan alması öngörülmüştür.

İkinci adım olarak ise, büyükşsehir belediyelerinin başarı düzeyi üzerinde etkili olması beklenen literatürde de yer verilen değişkenler ile "İç Kontrol Sistemi Değerlendirme Prosedürlerinin" puanlaması sonucu elde edilen başarı düzeyine ait veriler SPSS 23.0 (Statistical Package for the Social Sciences) programına girilmiş ve değişkenler arasında ilişkinin yönü ve istatistiksel olarak anlamlllığı korelasyon analizi ile test edilmiştir.

\section{Araştırmanın Verileri ve Bulguları}

35 prosedürü içeren “İç Kontrol Sistemi Değerlendirme Prosedürlerine” ait 5 temel prosedür sırasıyla "Kontrol Ortamı (KOP-7 prosedür), Risk Değerlendirme (RDP-8 prosedür), Kontrol Faaliyetleri (KFP-5 prosedür), Bilgi ve İletişim (BIP-6 prosedür) ile İzleme (IP-9 prosedür) Prosedürleri"dir. Büyükşsehir belediyelerinin Sayıştay 2019 yılı Denetim Raporlarındaki bilgilere göre 5 temel prosedüre ait her bir alt prosedürünün puanlaması yapılarak ilgili belediyenin İç Kontrol Sistemi Değerlendirme Prosedürleri (İKSDP) toplam puanına ulaşılmışırır.

\section{Kontrol Ortamı Prosedürlerine İlişkin Veri ve Bulgular}

Kontrol Ortamı Prosedürlerine ilişkin 7 soru bulunmaktadır. Bu bölümdeki prosedürlerin 1. sorusunda belediyenin organizasyon yapısı içerisinde görev, yetki ve sorumluluklar açık bir şekilde belirlenip yazılı halde olup olmadığı sorgulanmıştır. Bu soruya ilişkin bilgi Denizli, Eskişehir, Muğla ve Ordu büyükşehir belediyelerinin denetim raporlarında tespit edilememiştir (İlgili belediyelere puan verilmemiştir.). Erzurum büyükşehir belediyesinin sadece Mali Hizmetler Daire Başkanlığında görev tanımları yetki ve sorumlulukların belirlenerek iş süreçlerine ilişkin çalışmaların yapıldığı ve de üst yönetimin onayına sunulduğu; diğer daire başkanlıklarında ise görev tanımları yetki ve sorumlulukların belirlenmediği, iş tanımları ve işlerin süreçlerine ilişkin çalışma yapılmadığı, iş akış şemaları çıkarılmadığı görülmüştür (İlgili belediyeye 1 puan verilmiştir.). Trabzon belediyesinin, büyükşehre dönüşümü sebebiyle kurum misyonu ile birimlerin ve personelin görev tanımlarının yazılı olarak belirlenmesine yönelik ön çalışmaların tamamlandığı, ancak henüz meclis tarafından onaylanmadığı ifade edilmiştir (İlgili belediyeye 2 puan verilmiştir.). Diğer büyükşehir belediyelerinin tamamının denetim raporlarında belediyenin organizasyon yapısı içerisinde görev, yetki ve sorumluluklar açı bir şekilde belirlenip yazılı halde olduğu ifade edilmiştir (İlgili belediyelere 4 puan verilmiştir.).

Kontrol Ortamı Prosedürlerinin 2. sorusunda; belediyelerde yetki devirleri ve sinırlarının yazılı olarak belirlenip belirlenmediği sorgulanmıştır. 12 büyükşehir belediyesi yetki devirleri ve sınırlarının yazılı olarak belirlerken Erzurum, Malatya, Sakarya ve Trabzon büyükşehir belediyelerinde kuruma ait teşkilat şeması ve yetki devri ile ilgili çalışmaların devam ettiği veya belirlenmediği tespit edilmiştir. Bu bölümün 3. sorusunda; belediyede "Kamu Görevlileri Etik Davranış İlkeleri" ile ilgili eğitim ve bilgilendirme çalışmalarının yapılıp yapılmadığı sorgulanmıştır. Kamu Görevlileri Etik Davranış İlkeleri ile Başvuru Usul ve Esasları Hakkında Yönetmelik Ekinde yer alan "Etik Sözleşmesini” tüm büyükşehir belediyeleri personeli tarafından imzalanmış ve personel dosyalarına konulmuştur. Fakat eğitim ve bilgilendirme çalışmaları yapılmamıştır (İlgili belediyelere 2 puan verilmiştir.). Etik Sözleşmesini imzalamanın dışında eğitim ve bilgilendirme çalışmaları yapan sadece İzmir ve Balıkesir büyükşehir belediyeleridir (İlgili belediyelere 4 puan verilmiştir.).

Kontrol Ortamı Prosedürlerinin 4. sorusunda; belediye personelinin işe alınması, yer değiştirmesi, görevde yükselmesi, yeterliliği, performans değerlendirmesi ile disiplin hükümlerine yönelik insan kaynakları politikasının belirlenmesi ve çalışanlarına duyurulması faaliyetleri sorgulanmıştır. Adana, Aydın, Balıkesir, İzmir, Kahramanmaraş, Muğla, Tekirdağ ve Trabzon büyükşehir belediyelerinde yer değiştirme, üst görevlere atanma, eğitim, özlük hakları gibi insan kaynakları yönetimine ilişkin hususların yazılı olarak belirlenerek 
personele duyurulduğu bilgisi varken diğer belediyelerin denetim raporlarında bu soruya yönelik bilgiye ulaşılamamıştır. Bu bölümün 5. sorusunda; belediyenin hassas görevlere ilişkin prosedürleri belirleyip belirlemediği sorgulanmıştır. Hassas görevlere ilişkin prosedürleri belirleyen 7 belediye varken bu tür görevlere ilişkin prosedürlerin Diyarbakır Büyükşehir Belediyesi tarafından belirlenmediği görülmüştür (Diyarbakır Büyükşsehir Belediyesi 2019 Yılı Sayıştay Denetim Raporu, 2020, s. 9-10). Adana büyükşehir belediyesi tüm birimlerden hassas görevlere ilişkin prosedürleri belirlemeleri talep edilirken, Kocaeli büyükşehir belediyesinde ilgili prosedürlerin belirlemesi çalışmalarına devam edildiği ifade edilirken diğer belediyelerin denetim raporlarında hassas görevlere ilişkin herhangi bir bilgiye yer verilmemiştir.

Kontrol Ortamı Prosedürlerinin 6. sorusunda; belediyelerde ihtiyaç analizine dayalı hizmet içi eğitim planlaması yapılıp yapılmadığı sorgulanmıştır. Eğitim ihtiyaç analizleri yapılarak gerekli eğitimleri sürekli yapan sadece 8 belediyenin olduğu tespit edilirken diğer belediyelerin denetim raporlarında eğitim faaliyetlerine ilişkin herhangi bir bilgiye yer verilmemiştir. Bu bölümün 7. ve son sorusunda; belediyelerin bu bölümde yer alan prosedürleri değerlendirildiğinde iç kontrol sistemi ve kurumsal risk yönetimi üst yönetim ve kurum personeli tarafından sahiplenilip sahiplenilmediği değerlendirilmiştir. Belediyelerin üst yönetim ve çalışanlarının iç kontrol sisteminin geliştirilmesi yönündeki pozitif ve destekleyici tavırlarının, sistemin mevzuata uygun şekilde kurulması açısından olumlu olduğu değerlendirilen belediyeler; Aydın, Eskişehir, Manisa ve Samsun büyükşehir belediyeleridir. Antalya, Balıkesir, Kayseri, Şanlıurfa ve Trabzon büyükşehir belediyelerinde iç kontrol sisteminin ve işleyişinin üst yönetici ve personel tarafından sahiplenilmeye ve desteklenmeye çalışıldığı tespit edilirken diğer belediyelerin denetim raporlarında herhangi bir bilgiye yer verilmemiştir.

\section{Risk Değerlendirme Prosedürlerine iliş̧in Veri ve Bulgular}

Risk Değerlendirme Prosedürlerine ilişkin 8 soru bulunmaktadır. Bu bölümdeki prosedürlere ilişkin olarak 1., 2., 3. ve 4. sorular belediyenin stratejik planı, performans programı ve bütçesine yöneliktir. Denizli, Eskişehir, Muğla ve Ordu büyükşehir belediyelerinin stratejik planlarına ilişkin herhangi bir olumlu/olumsuz bilgi tespit edilmezken diğer büyükşehir belediyelerinin, çalışanlarının katılımıyla ve ilgili mevzuat gereklilikleriyle uyumlu bir çerçevede stratejik plan ve stratejik planın yıllık uygulamasına yönelik performans programı hazırladıkları ifade edilmiştir. Fakat performans hedefleri ve bu hedeflere ilişkin faaliyetlerin bütçe kaynaklarına ilişkilendirerek bütçe oluşturan belediyeler olarak Aydın, Eskişehir, Kahramanmaraş, Sakarya ve Van büyükşehir belediyelerinin olduğu ilgili belediyelerin denetim raporlarında ifade edilmiştir. Diğer belediyelere ait herhangi bir bilgiye raporlarda yer verilmemiştir.

Risk Değerlendirme Prosedürlerine ilişkin 5., 6., 7. ve 8. sorular belediyenin kurumsal ve iç kontrol risklerinin belirlenmesi ve risklerin değerlendirilmesine yöneliktir. Belediyelerin iç ve dış risklerin belirlenmesinin sadece stratejik planlama hazırlığı sürecinde gündeme geldiği, sonrasında bu alanda herhangi bir çalışma yapılmadığg ve yapılmamasının nedenlerinden birisinin de bu konuda gerekli eğitimleri almış personel eksikliğinden kaynaklandığının belediye tarafından ifade edildiği tespit edilmiştir (Manisa Büyükşehir Belediyesi 2019 Yılı Sayıştay Denetim Raporu, 2020, s. 9). 12 büyükşehir belediyesi tarafından kurumsal risk yönetim çalışmalarının yapıldığı; Diyarbakır, Samsun, Trabzon ve Van büyükşehir belediyelerinde ise yapılmadığı sonucuna ulaşlırken diğer büyükşehir belediyelerinin denetim raporlarında konu ile ilgili herhangi bir bilgiye rastlanılmamıştır.

\section{Kontrol Faaliyetleri Prosedürlerine ilişkin Veri ve Bulgular}

Kontrol Faaliyetleri Prosedürlerine ilişkin 5 soru bulunmaktadır. Bu bölümdeki prosedürlerin 1. sorusu; belediyelerdeki iş akış süreçlerinin belirlenip belirlenmediğinin sorgulanmasına yöneliktir. 21 büyükşehir belediyesi iş süreçlerini ve iş akış şemalarını belirlerken Diyarbakır, Erzurum, Malatya ve Samsun büyükşehir belediyelerinin çalışmalarına devam ettiği tespit edilmiştir. Kontrol Faaliyetleri Prosedürlerine ilişkin 2. soru 
idarenin yaptığı görevlendirmelerdeki görevler ayrılığına yöneliktir. Bazı belediyelerde personel mevcudu yetersizliğinden dolayı bu usul ve esaslara tam olarak uyulmadığı performans denetim raporlarında ifade edilmekle birlikte Denizli ve Ordu büyükşehir belediyelerinde muhasebe yetkililerinin muhasebe yetkilisi sertifikası bulunmadığı tespit edilmiştir (Denizli Büyükşehir Belediyesi 2019 Yılı Sayıştay Denetim Raporu, 2020, s. 7; Ordu Büyükşehir Belediyesi 2019 Yılı Sayıştay Denetim Raporu, 2020, s. 14).

Kontrol Faaliyetleri Prosedürlerine ilişkin 3. ve 4. soru belirlenen risklerin kabul edilebilir düzeye indirilmesine yönelik kontrol faaliyetlerin oluşturulmasına ve bu faaliyetlerin uygulanmasında sorumluların belirlenmesine yöneliktir. Belediyelerin iç ve dış risklerinin belirlenmesini sadece stratejik planlama hazırlığı sürecinde gündeme getirdikleri için risklerin kontrolüne yönelik faaliyet standartlarına ilişkin olarak riskleri karşılamaya uygun kontrol stratejileri sadece Malatya büyükşehir belediyesinin belirlediği görülmüştür. Bu bölümün 5. ve son sorusu belediyelerin ön mali kontrol sisteminin, İç Kontrol ve Ön Mali Kontrole İlişkin Usul ve Esaslara uygun olarak kurulmuş olup olmamasına yöneliktir. 21 büyükşehir belediyesinde ön mali kontrol sisteminin, İç Kontrol ve Ön Mali Kontrole İlişkin Usul ve Esaslara uygun olarak kurulurken Kocaeli Büyükşehir Belediyesinde iç kontrol ve ön mali kontrol aktif hale getirilemeyerek ön mali kontrole tabi karar ve işlemlere yönelik herhangi bir belirleme yapılmadığı tespit edilmiştir. Balıkesir Büyükşehir Belediyesinde ise Ön Mali Kontrol Yönergesi düzenlenmiş olup İç Kontrol ve Ön Malî Kontrole İlişkin Usul ve Esaslarda belirtilen parasal sınırları aşan işlemler bu esaslara uygun olarak ön mali kontrole tabi tutulmakla birlikte, ön mali kontrole ilişkin idari bir yapılanma mevcut olmadığı görülmüştür.

\section{Bilgi ve İletişim Prosedürlerine ilişkin Veri ve Bulgular}

Bilgi ve İletişim Prosedürlerine ilişkin 6 soru bulunmaktadır. Bu bölümdeki prosedürlerin 1. sorusunda yönetimin ihtiyaç duyduğu gerekli bilgileri ve raporları üretecek ve analiz yapma imkânı sunacak bir yönetim bilgi sisteminin belediyede mevcudiyeti sorgulanmıştır. 16 büyükşehir belediyesinde yönetim bilgi sisteminin var olduğuna ilişkin bilgi denetim raporlarında tespit edilirken diğer 14 belediyede ise bu veriye ilişkin herhangi bir bilgiye rastlanılmamıştır.

Bilgi ve İletişim Prosedürlerine ilişkin 2., 3. ve 4. sorular belediyelerin faaliyet raporlarına yöneliktir. 16 büyükşehir belediyesinin mevzuata uygun faaliyet raporu hazırladı̆̆ bilgisine denetim raporlarında ulaşılmıştır. 13 büyükşehir belediyesinin ise faaliyet sonuçlarına ilişkin bilgilerden oluşması gerekli olan idare faaliyet raporunu içerik olarak mevzuata uygun hazırlanmakla beraber kamuoyu ile belediyenin web sayfasında yayınlayarak paylaştığı bilgisi denetim raporlarında verilmiştir. Diğer belediyelerin denetim raporlarında faaliyet raporlarına ilişkin herhangi bir bilgiye rastlanılmamıştır.

Bilgi ve İletişim Prosedürlerine ilişkin bölümdeki 5. ve 6. sorularda belediyede veri kayıt ve dosyalama sisteminin varlığı ile bilgi yönetim sisteminin etkinliği sorgulanmıştır. Adana, İzmir, Konya, Malatya ve Sakarya büyükşehir belediyelerinde veri kayıt ve dosyalama sisteminin mevcut olduğu tespit edilmiştir. Sakarya büyükşehir belediyesi gelen ve giden evrak ile idare içi haberleşmeyi kapsayacak kayıt ve dosyalama sistemi elektronik ortamda (SAKBİS Modülü) faaliyet gösterdiği ifade edilmiştir. Belediyelerdeki bu bilgi yönetim sistemlerinin bilgi güvenliğini ve yedekleme gerekliliklerini sağlayacak şekilde dizayn edildiğine yönelik bilgi sadece Malatya ve Sakarya büyükşehir belediyeleri için ifade edilmiştir. Diğer belediyelerin denetim raporlarında veri kayıt ve dosyalama sisteminin varlığı ve bilgi yönetim sisteminin etkinliğine ilişkin herhangi bir bilgiye rastlanılmamıştır.

\section{İzleme Prosedürlerine iliş̧kin Veri ve Bulgular}

İzleme Prosedürlerine ilişkin 9 soru bulunmaktadır. Bu bölümdeki prosedürlerin 1. ve 2. soruları; belediyelerin İç kontrol Standartlarına Uyum Eylem Planının varlığı ve bu planın Kamu İç Kontrol Standartları Tebliğine uygun hazırlanıp hazırlanmadığına yöneliktir. Mardin büyükşehir belediyesi (İlgili belediyeye 0 puan verilmiştir.) hariç büyükşehir belediyeleri eylem planı hazırlamış veya girişimde bulunmuştur. Samsun, 
Trabzon ve Van büyükşehir belediyeleri tarafından ise İç Kontrol Eylem Planı hazırlanmaktadır (İlgili belediyelere 1 puan verilmiştir.). Diyarbakır büyükşehir belediyesi iç kontrol kurmak amacıyla ilgili "Usul ve Esaslar" ve "Kamu İç Kontrol Standartlarına Uyum Eylem Planı Rehberi” doğrultusunda çalışmalar yürütmüş ve iç kontrol standartlarının gerektirdiği koşulları sağlayabilmek için bir eylem planı oluşturmuş ancak hazırlanan bu eylem planı uygulamaya konulamadığı ifade edilmiştir (İlgili belediyeye 2 puan verilmiştir.) (Diyarbakır Büyükşehir Belediyesi 2019 Yılı Sayıştay Denetim Raporu, 2020, s. 9-10).

İzleme prosedürlerin 3., 4., 5. ve 6. soruları; belediyelerde üst yöneticinin onayı ile görevlendirilen İç Kontrol İzleme ve Yönlendirme Kurulu ile bu kurulun iç kontrol sistemini değerlendirmesine yönelik raporları hazırlaması ve raporların üst yönetici sunularak iç kontrol sistemine ilişkin tespit edilen yetersizliklerin giderilip giderilmediğine yöneliktir. Denetim raporlarında bu sorulara ilişkin bilgi verilmeyen belediyeler olmakla birlikte 12 büyükşehir belediyesinde İç Kontrol İzleme ve Yönlendirme Kurulu oluşturulmuş olmasına rağmen 4 büyükşehir belediyesinde (Bursa, Diyarbakır, Malatya ve Van) bu kurul oluşturulmamıştır. Kurul oluşturan belediyenin tüm birimleri tarafından iç kontrol sistemini yılda en az bir kez değerlendirerek raporlayan ise sadece 6 büyükşehir belediyesidir (Aydın, Eskişehir, İstanbul, İzmir, Kahramanmaraş ve Kayseri).

İzleme prosedürleri bölümünün 7. ve 8. sorularında; belediyelerde çalışan iç denetçi sayılarının yeterliliği ile çalışan iç denetçilerin iç kontrol sistemine ilişkin denetim ve raporlama çalışmaları yapıp yapmadığı sorgulanmıştır. Antalya, İstanbul, Kahramanmaraş ve Şanlıurfa büyükşehir belediyelerin iç denetçi sayılarının yeterli olduğu ifade edilmiştir. 5018 sayılı Kanun gereğince, 20 adet iç denetçi kadrosu ve fiilen 19 iç denetçinin görev yaptı̆̆ İstanbul Büyükşehir Belediyesi’nin, İç Denetim Yönergesinin de hazırlanmış olmasına rağmen, en son iç denetim faaliyetinin 2014 yılında yapıldığı tespit edilmekle birlikte o tarihten bu yana iç denetim faaliyetleri kapsamında herhangi bir çalışma, plan ve programının olmadığı, İdarede herhangi bir denetim faaliyetin de yürütülmediği Sayıştay tarafından raporlanmıştır (İstanbul Büyükşehir Belediyesi 2019 Yılı Sayıştay Denetim Raporu, 2020, s. 14).

Sayıştay denetiminin gerçekleştirildiği tarih (2020 yılı) itibariyle 2019 denetim raporlarında denetçi sayısının yetersiz olduğu ifade edilen Balıkesir, Bursa, Malatya, Mardin, Sakarya ve Samsun büyükşehir belediyelerin 08.02.2021 tarihi itibariyle kamu idarelerindeki iç denetçi kadrolarına göre iç denetçi kadro doluluk sayısını artırdıkları tespit edilmiştir (İç Denetim Koordinasyon Kurulu, 08.02.2021). Balıkesir büyükşehir belediyesinde bir iç denetçi çalışırken bir iç denetçi daha çalışmaya başlamıştır. İç denetçisi bulunmayan Kocaeli ve Tekirdağ büyükşehir belediyelerine ilişkin olarak Sayıştay denetim raporlarında ise herhangi bir ifadeye rastlanılmamıştır. Bu bölümün 9. ve son sorusunda; belediyelerin üst yönetici olan belediye başkanının ve harcama birimlerinin iç kontrol güvence beyanını imzalayıp imzalamadığı sorgulanmıştır. 7 büyükşehir belediyesinin denetim raporlarında güvence beyanını imzaladıkları raporlanmış olmasına rağmen diğer 23 büyükşehir belediyesinin denetim raporunda herhangi bir bilgiye yer verilmemiştir.

\section{Büyükşehir Belediyelerinin İç Kontrol Sistemi Değerlendirme Prosedürlerine illişkin Veri ve Bulguları}

Büyükşehir belediyelerinin "Kontrol Ortamı, Risk Değerlendirme, Kontrol Faaliyetleri, Bilgi ve İletişim ile İzleme Prosedürlerinden" elde edilen veri ve bulguların bir araya getirilmesiyle her bir belediye ait "İç Kontrol Sistemi Değerlendirme Prosedürlerine" ilişkin Tablo 3’te verilen puanlara ulaşılmıştır. 
Tablo 3

Büyükşehir Belediyelerinin İç Kontrol Sistemi Değerlendirme Prosedürleri

\begin{tabular}{|c|c|c|c|c|c|c|}
\hline Büyükşehir Belediyesi & $\begin{array}{l}\text { Kontrol } \\
\text { Ortamı }\end{array}$ & $\begin{array}{c}\text { Risk } \\
\text { Değerlendirme }\end{array}$ & $\begin{array}{c}\text { Kontrol } \\
\text { Faaliyetleri }\end{array}$ & $\begin{array}{l}\text { Bilgi ve } \\
\text { İletişim }\end{array}$ & İzleme & Toplam \\
\hline Mersin & * & $*$ & $*$ & * & * & * \\
\hline Aydin & 26 & 32 & 8 & 16 & 13 & 95 \\
\hline Kahramanmaraş & 22 & 24 & 12 & 4 & 24 & 86 \\
\hline Malatya & 11 & 19 & 16 & 24 & 9 & 79 \\
\hline İzmir & 20 & 12 & 12 & 12 & 20 & 76 \\
\hline Kayseri & 13 & 20 & 8 & 16 & 17 & 74 \\
\hline Konya & 18 & 8 & 8 & 20 & 15 & 69 \\
\hline Şanliurfa & 13 & 20 & 8 & 12 & 16 & 69 \\
\hline Antalya & 13 & 22 & 7 & 12 & 12 & 66 \\
\hline Sakarya & 6 & 19 & 4 & 24 & 9 & 62 \\
\hline Eskişehir & 6 & 16 & 4 & 12 & 21 & 59 \\
\hline Trabzon & 20 & 8 & 12 & 8 & 6 & 54 \\
\hline İstanbul & 14 & 8 & 7 & 4 & 20 & 53 \\
\hline Kocaeli & 16 & 12 & 9 & 8 & 4 & 49 \\
\hline Balıkesir & 11 & 24 & 1 & 8 & 5 & 49 \\
\hline Erzurum & 3 & 16 & 5 & 12 & 7 & 43 \\
\hline Tekirdağ & 22 & 0 & 8 & 7 & 4 & 41 \\
\hline Bursa & 10 & 8 & 8 & 8 & 6 & 40 \\
\hline Samsun & 14 & 8 & 5 & 9 & 2 & 38 \\
\hline Adana & 9 & 9 & 4 & 4 & 12 & 38 \\
\hline Van & 6 & 16 & 8 & 4 & 2 & 36 \\
\hline Ankara & 4 & 12 & 4 & 12 & 4 & 36 \\
\hline Manisa & 10 & 0 & 8 & 4 & 13 & 35 \\
\hline Hatay & 8 & 8 & 8 & 0 & 9 & 33 \\
\hline Ordu & 0 & 8 & 4 & 8 & 6 & 26 \\
\hline Diyarbakır & 6 & 0 & 5 & 4 & 5 & 20 \\
\hline Denizli & 2 & 0 & 4 & 0 & 11 & 17 \\
\hline Gaziantep & 4 & 0 & 8 & 0 & 4 & 16 \\
\hline Muğla & 3 & 0 & 3 & 0 & 5 & 11 \\
\hline Mardin & 0 & 0 & 0 & 0 & 0 & 0 \\
\hline
\end{tabular}

Mersin Büyükşehir Belediyesi 2019 Yılı Sayıştay Denetim Raporunda (2020, s. 6) "Kurumun iç kontrol sistemi hakkında bilgi edinilmesi amacıyla; ilgili mevzuat ve yapılan anket esas alınarak yapılan ilk incelemeler sonucunda; İç kontrol sisteminin kurulması, uygulanması, izlenmesi ve geliştirilmesi yönünde, yürürlükteki İç Kontrol mevzuatı gereklerinin yerine getirildiği anlaşılmıştır.” ifadelerine yer verilmiştir. Belediyenin iç kontrol sisteminin değerlendirme prosedürlerini yerine getirme durumuyla ilgili herhangi bir bilgiye denetim raporunda rastlanılmamış olması nedeniyle puanlama yapılmamıştır.

Büyükşehir belediyelerinin "İç Kontrol Sistemi Değerlendirme Prosedürlerindeki” 5 unsura ait 35 prosedüre 0-4 puan aralığında yapılan değerlendirmede bu prosedürleri etkin bir şekilde uygulayan belediyenin maksimum 140 puan alması gerekliliği göz önüne alındığında büyükşehir belediyelerin performansının oldukça düşük olduğu Tablo 5’te görülmektedir. 30 belediyenin ortalama başarı düzeyi 47,24’tür. En yüksek puanı 95 puan ile Aydın büyükşehir belediyesi alırken en düşük puanı ise Mardin büyükşehir belediyesi almıştır.

Büyükşehir belediyelerinin başarı düzeyi üzerinde etkili olması beklenen literatürde de yer verilen değişkenler ile "İç Kontrol Sistemi Değerlendirme Prosedürlerinin" puanlaması sonucu elde edilen başarı düzeyine ait veriler SPSS 23.0 (Statistical Package for the Social Sciences) programına girilmiş ve değişkenler arasında 
ilişkinin yönü ve istatistiksel olarak anlamlılığı korelasyon analizi ile test edilmiştir. Bağımlı değişken; 30 büyükşehir belediyesinin 2019 yılında Sayıştay tarafından gerçekleştirilen denetimin raporlarındaki verilerden yararlanılarak "İç Kontrol Sistemi Değerlendirme Prosedürlerinin” puanlaması elde edilen başarı düzeyidir.

Tablo 4

Bağımlı Değişkene Ait Tanımlayıcı İstatistikler

\begin{tabular}{ll}
\hline Örneklem & 30 \\
Ortalama & 47,24 \\
Standart Sapma & 4,382 \\
Maksimum Puan & 95 \\
Minimum Puan & 0 \\
\hline
\end{tabular}

Bağımsız değişkenler; Belediyenin İç Denetçi Dolu Kadro Sayısı-X $X_{1}$, İç Denetim Rapor Sayısı- $X_{2}, 2019$ yılı Gerçekleşen Bütçe Giderleri- $\mathrm{X}_{3}$, 2019 yılı Gerçekleşen Bütçe Geliri- $\mathrm{X}_{4}$, Bütçe Dengesi - $\mathrm{X}_{5}$, Nüfus- $\mathrm{X}_{6}$, Coğrafi Bölge - $\mathrm{X}_{7}$, Siyasi İdeoloji- $\mathrm{X}_{8}$, Başkanının Eğitim Düzeyi - $\mathrm{X}_{9}$ ve Başkanın Cinsiyeti- $\mathrm{X}_{10}$ olarak belirlenmiştir ${ }^{11}$.

Tablo 5

Korelasyon Analizi

\begin{tabular}{|c|c|c|c|c|c|c|c|c|c|c|c|c|}
\hline & & $\begin{array}{l}\text { Bağımlı } \\
\text { Değişken }\end{array}$ & $\mathrm{X}_{1}$ & $\mathrm{X}_{2}$ & $\mathrm{X}_{3}$ & $\mathrm{X}_{4}$ & $\mathrm{X}_{5}$ & $\mathrm{X}_{6}$ & $\mathrm{X}_{7}$ & $\mathrm{X}_{8}$ & $\mathrm{X}_{9}$ & $\mathrm{X}_{10}$ \\
\hline \multirow{3}{*}{$\begin{array}{l}\text { Bağımlı } \\
\text { Değişken }\end{array}$} & $\begin{array}{l}\text { Pearson } \\
\text { Correlation }\end{array}$ & 1 & , 134 & , 183 & ,086 & ,081 & ,113 & ,074 &,- 072 &,$- 388^{*}$ &,- 231 & ,097 \\
\hline & $\begin{array}{l}\text { Sig. (2- } \\
\text { tailed) }\end{array}$ & & , 489 & ,341 & ,657 & 678 & ,559 & ,704 & ,711 & ,038 & ,228 & 617 \\
\hline & $\mathrm{N}$ & 29 & 29 & 29 & 29 & 29 & 29 & 29 & 29 & 29 & 29 & 29 \\
\hline \multirow{3}{*}{$\mathrm{X}_{1}$} & $\begin{array}{l}\text { Pearson } \\
\text { Correlation }\end{array}$ & ,134 & 1 &, $470^{* *}$ &, $888^{* *}$ &, $892^{* *}$ &, $651^{* *}$ & $907^{* *}$ &,- 001 & ,073 &,- 037 &,- 042 \\
\hline & $\begin{array}{l}\text { Sig. }(2- \\
\text { tailed) }\end{array}$ & ,489 & & ,009 & ,000 & ,000 & ,000 & ,000 & ,997 & ,701 & ,847 & ,826 \\
\hline & $\mathrm{N}$ & 29 & 30 & 30 & 30 & 30 & 30 & 30 & 30 & 30 & 30 & 30 \\
\hline \multirow{3}{*}{$\mathrm{X}_{2}$} & $\begin{array}{l}\text { Pearson } \\
\text { Correlation }\end{array}$ & ,183 &, $470^{* *}$ & 1 & ,193 & ,196 & ,124 & ,220 &,- 187 & ,107 &,- 134 &,- 002 \\
\hline & $\begin{array}{l}\text { Sig. (2- } \\
\text { tailed) }\end{array}$ & ,341 & ,009 & & ,307 & ,300 & ,513 & ,242 & ,322 &, 572 & ,481 & 993 \\
\hline & $\mathrm{N}$ & 29 & 30 & 30 & 30 & 30 & 30 & 30 & 30 & 30 & 30 & 30 \\
\hline \multirow{3}{*}{$\mathrm{X}_{3}$} & $\begin{array}{l}\text { Pearson } \\
\text { Correlation }\end{array}$ & ,086 &, $888^{* *}$ & ,193 & 1 &, $997^{* *}$ &, $796^{* *}$ &, $987^{* *}$ & ,240 & ,044 & ,090 &,- 066 \\
\hline & $\begin{array}{l}\text { Sig. }(2- \\
\text { tailed) }\end{array}$ & ,657 & ,000 & ,307 & & ,000 & ,000 & ,000 & ,202 & ,816 & ,636 & ,727 \\
\hline & $\mathrm{N}$ & 29 & 30 & 30 & 30 & 30 & 30 & 30 & 30 & 30 & 30 & 30 \\
\hline \multirow{3}{*}{$\mathrm{X}_{4}$} & $\begin{array}{l}\text { Pearson } \\
\text { Correlation }\end{array}$ & ,081 &, $892^{* *}$ & ,196 &, $997^{* *}$ & 1 &, $750^{* *}$ &, $992^{* *}$ & ,257 & ,044 & ,079 &,- 074 \\
\hline & $\begin{array}{l}\text { Sig. }(2- \\
\text { tailed })\end{array}$ & ,678 & ,000 & ,300 & ,000 & & ,000 & ,000 & ,170 & ,816 & ,679 & ,697 \\
\hline & $\mathrm{N}$ & 29 & 30 & 30 & 30 & 30 & 30 & 30 & 30 & 30 & 30 & 30 \\
\hline
\end{tabular}

${ }^{11}$ Coğrafi Bölge- $\mathrm{X}_{7}$, Siyasi İdeoloji- $\mathrm{X}_{8}$, Başkanının Eğitim Düzeyi- $\mathrm{X}_{9}$ ve Başkanın Cinsiyeti- $\mathrm{X}_{10}$ süreksiz (kategorik) bağımsız değişkenler olmakla birlikte korelasyon analizinde sürekli değișken haline dönüştürülmüştür. 
Tablo 5

Korelasyon Analizi (Devami)

\begin{tabular}{|c|c|c|c|c|c|c|c|c|c|c|c|c|}
\hline & & $\begin{array}{l}\text { Bağımlı } \\
\text { Değişsken }\end{array}$ & $\mathrm{X}_{1}$ & $\mathrm{X}_{2}$ & $\mathrm{X}_{3}$ & $\mathrm{X}_{4}$ & $\mathrm{X}_{5}$ & $\mathrm{X}_{6}$ & $\mathrm{X}_{7}$ & $\mathrm{X}_{8}$ & $\mathrm{X}_{9}$ & $\mathrm{X}_{10}$ \\
\hline \multirow{3}{*}{$\mathrm{X}_{5}$} & $\begin{array}{l}\text { Pearson } \\
\text { Correlation }\end{array}$ & ,113 &, $651^{* *}$ & , 124 &, $796^{* *}$ &, $750^{* *}$ & 1 &, $723^{* *}$ & ,039 & ,034 & , 166 & ,014 \\
\hline & $\begin{array}{l}\text { Sig. }(2- \\
\text { tailed) }\end{array}$ & ,559 & ,000 & ,513 & ,000 & ,000 & &, 000 & ,839 & ,858 & ,381 & ,944 \\
\hline & $\mathrm{N}$ & 29 & 30 & 30 & 30 & 30 & 30 & 30 & 30 & 30 & 30 & 30 \\
\hline \multirow{3}{*}{$\mathrm{X}_{6}$} & $\begin{array}{l}\text { Pearson } \\
\text { Correlation }\end{array}$ & ,074 & $907^{* *}$ & ,220 &, $987^{* *}$ &, $992^{* *}$ &, $723^{* *}$ & 1 & ,240 & ,059 & ,073 &,- 056 \\
\hline & $\begin{array}{l}\text { Sig. (2- } \\
\text { tailed) }\end{array}$ & ,704 & ,000 & ,242 & ,000 & ,000 & ,000 & & ,202 & ,757 & ,702 & ,769 \\
\hline & $\mathrm{N}$ & 29 & 30 & 30 & 30 & 30 & 30 & 30 & 30 & 30 & 30 & 30 \\
\hline \multirow{3}{*}{$\mathrm{X}_{7}$} & $\begin{array}{l}\text { Pearson } \\
\text { Correlation }\end{array}$ &,- 072 &,- 001 &,- 187 & ,240 & ,257 & ,039 & ,240 & 1 &,- 282 &,- 005 &,- 072 \\
\hline & $\begin{array}{l}\text { Sig. }(2- \\
\text { tailed) }\end{array}$ & ,711 & ,997 & ,322 & ,202 & , 170 & ,839 & ,202 & & ,131 & ,980 & ,704 \\
\hline & $\mathrm{N}$ & 29 & 30 & 30 & 30 & 30 & 30 & 30 & 30 & 30 & 30 & 30 \\
\hline \multirow{3}{*}{$\mathrm{X}_{8}$} & $\begin{array}{l}\text { Pearson } \\
\text { Correlation }\end{array}$ &,$- 388^{*}$ & ,073 & , 107 & ,044 & ,044 & ,034 & ,059 & ,282 & 1 &, $584^{* *}$ &,- 067 \\
\hline & $\begin{array}{l}\text { Sig. }(2- \\
\text { tailed) }\end{array}$ & ,038 & ,701 & ,572 & ,816 & ,816 & ,858 & ,757 & ,131 & & ,001 & ,724 \\
\hline & $\mathrm{N}$ & 29 & 30 & 30 & 30 & 30 & 30 & 30 & 30 & 30 & 30 & 30 \\
\hline \multirow{3}{*}{$\mathrm{X}_{9}$} & $\begin{array}{l}\text { Pearson } \\
\text { Correlation }\end{array}$ &,- 231 &,- 037 &,- 134 & ,090 & ,079 & , 166 & ,073 & 005 &, $584^{* *}$ & 1 &,- 242 \\
\hline & $\begin{array}{l}\text { Sig. }(2- \\
\text { tailed })\end{array}$ & ,228 & ,847 & ,481 & ,636 & ,679 & ,381 & ,702 & ,980 & ,001 & & , 198 \\
\hline & $\mathrm{N}$ & 29 & 30 & 30 & 30 & 30 & 30 & 30 & 30 & 30 & 30 & 30 \\
\hline \multirow[b]{2}{*}{$\mathrm{X}_{10}$} & $\begin{array}{l}\text { Pearson } \\
\text { Correlation }\end{array}$ & ,097 &,- 042 &,- 002 &,- 066 &,- 074 & ,014 &,- 056 & ,072 &,- 067 &,- 242 & 1 \\
\hline & $\begin{array}{l}\text { Sig. (2- } \\
\text { tailed) }\end{array}$ & ,617 & ,826 & ,993 & ,727 & ,697 & 944 &, 769 & ,704 & ,724 & , 198 & \\
\hline 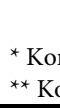 & $\begin{array}{l}\mathrm{N} \\
05 \text { düzeyinde anl } \\
, 01 \text { düzeyinde an }\end{array}$ & $\begin{array}{l}\text { dir. } \\
\text { idır. }\end{array}$ & 30 & 30 & 30 & 30 & 30 & 30 & 30 & 30 & 30 & 30 \\
\hline
\end{tabular}

Tablo 5’teki korelasyon analizine göre bağımlı değişken olan 30 büyükşehir belediyesinin 2019 yılı Sayıştay tarafından gerçekleştirilen denetimin raporlarındaki verilerden yararlanılarak "İç Kontrol Sistemi Değerlendirme Prosedürlerinin" puanlaması elde edilen başarı düzeyi ile sadece $\mathrm{X}_{8}$ (Siyasi İdeoloji) $(\mathrm{r}=-0,388)$ arasında istatiksel olarak 0,05 anlamlılık düzeyinde negatif bir ilişki tespit edilmiştir. Belediye başkanın temsil ettiği siyasi ideolojiye (görüşüne) göre; 15 büyükşehir belediyesi Adalet ve Kalkınma Partisi (AKP)'nin, 11 büyükşehir belediyesi Cumhuriyet Halk Partisi (CHP)'nin, 1 büyükşehir belediyesi Milliyetçi Hareket Partisi (MHP)'nin ve 3 büyükşehir belediyenin başkanı ise kayyum olarak tespit edilmiştir. Belediye başkanın kayyum olarak atandığı belediyelerde "İç Kontrol Sistemi Değerlendirme Prosedürlerinin" puanlanmasıyla elde edilen başarı düzeyi diğer belediyelere göre kısmi olarak daha düşük bulunmuştur.

Korelasyon analizi sonucunda belediyenin iç denetçi dolu kadro sayısı, iç denetim rapor sayısı, gerçekleşen bütçe giderleri, 2019 yılı gerçekleşen bütçe geliri, bütçe dengesi, nüfusu, coğrafi bölgesi, başkanının eğitim düzeyi ve başkanın cinsiyeti arasında istatiksel olarak bir ilişki tespit edilememiştir. 


\section{Sonuç}

Çalışmada 30 büyükşehir belediyesine ait Sayıştay 2019 yılı Denetim Raporlarındaki 35 adet prosedürü içeren "İç Kontrol Sistemi Değerlendirme Prosedürleri” bilgilerinin değerlendirilmesi yapılmış ve uygulanma düzeyinin puanlanması yapılarak ilgili belediyenin "İç Kontrol Sistemi Değerlendirme Prosedürleri” toplam puanına ulaşılmıştır. Büyükşehir belediyelerinin iç kontrol sistemi performansının oldukça düşük olduğu tespit edilmiştir. 30 belediyenin ortalama başarı düzeyinin maksimum puan olan 140 üzerinden 47,24 olarak bulunmuştur.

Büyükşehir belediyelerinin iç kontrol sistemi performanslarının oldukça düşük olmasına rağmen Mardin Büyükşehir Belediyesi hariç diğer bütün büyükşehir belediyelerinin eylem planı hazırladıkları ya da hazırlama girişiminde bulundukları tespit edilmiştir. Ayrıca "İç Kontrol Sistemi Değerlendirme Prosedürleri” içerisinde yer alan ve 5018 sayılı Kanunun 9. maddesinin de gerekliliklerin başında bulunan stratejik planlamaya dayalı performans esaslı bütçeleme sisteminin sac ayakları olan stratejik plan, performans programı ve faaliyet raporunu hazırladıkları tespit edilmiştir. Fakat belediyelerin kurumsal ve iç kontrol risklerini belirlediklerine dair herhangi bir bilgiye ulaşılamamıştır.

Çalışmada içerik analiziyle, Sayıştay 2019 yılı Denetim Raporlarındaki bilgilere dayanılarak 35 adet prosedürü içeren "İç Kontrol Sistemi Değerlendirme Prosedürlerini" belediyelerin uygulama düzeyinin bilgisi puanlandırıldığında (en az puana sahip belediyeden en çok puan alan belediye doğru yapılan sıralamada) ilk sırada 95 puan ile Aydın Büyükşehir Belediyesi bulunurken son sırada Mardin Büyükşehir Belediyesinin yer aldığı tespit edilmiştir. Yapılan sıralama sonrasında belediyelerin iç kontrol sisteminin performansı üzerinde belirlenen değişkenlerin etkinliğini sorgulamak için ise korelasyon analizi yapılmıştır.

Literatürde yer alan ve korelasyon analizinde kullanılan diğer değişkenlerle (Belediyenin İç Denetçi Dolu Kadro Sayısı, İç Denetim Rapor Sayısı, 2019 yılı Gerçekleşen Bütçe Giderleri ve Gelirleri, Bütçe Dengesi, Nüfus, Coğrafi Bölge, Başkanının Eğitim Düzeyi ve Cinsiyeti) istatistiksel olarak herhangi bir pozitif veya negatif ilişki tespit edilememiştir. Sadece siyasi ideoloji ile iç kontrol performansı arasında istatistiksel olarak anlamlı negatif bir ilişki tespit edilmiştir. Analiz sonucunda belediye başkanın kayyum olarak atandığı 3 büyükşehir belediyesinde "İç Kontrol Sistemi Değerlendirme Prosedürlerinin" puanlanmasıyla elde edilen başarı düzeyinin diğer büyükşehir belediyelerine kıyasla kısmi olarak daha düşük olduğu tespit edilmiştir.

Çalışmanın iki temel kısıttı vardır. İlk kısıttı veri sayısıdır. Çalışmada homojenlik sağlanması açısından sadece büyükşehir belediyeleri dâhil edildiğinden sadece 30 adet büyükşehir belediyesinin verileri kullanılmıştır. Çalışmanın önemli bir diğer kısıttı ise iç kontrol sisteminin kamu idarelerinde henüz etkin bir uygulama ortamının oluşmamış olması ve iç kontrol sisteminin değerlendirilmesinde standart bir çerçeve olmamasıdır. Veri sayısının arttırılması ve farklı kamu idarelerinde yapılacak çalışmalarda elde edilecek sonuçların daha anlamlı olacağı öngörülmektedir. 


\section{Kaynakça}

26.12.2007 Tarih ve 26738 sayılı Resmî Gazete Kamu İç Kontrol Standartları Tebliği.

Ağdeniz, Ş. (2019). Kurumsal risk yönetimi ve iç denetim. Eskişehir: Nisan Kitabevi.

Ağmaz, S. (2017). Türkiyede’ki belediyelerin iç kontrol sistemlerinin etkinliğinin dış denetim bulgularına göre analizi. Kastamonu University Journal of Faculty of Economics and Administrative Sciences, 19(4), 74-92. doi:10.21180/kuiibf.2017434556 74

Akyel, R. (2010). Türkiye'de iç kontrol kavramı, unsurları ve etkinliğinin değerlendirilmesi. Yönetim ve Ekonomi, 17(1), 83-97. Erişim adresi: https://dergipark.org.tr/en/pub/yonveek/issue/13692/165713

Aramide, S. F. ve Bashir, M. M. (2015). The effectiveness of internal control system and financial accountability at local government level in Nigeria. International Journal of Research in Business Management, 3(8), 1 -

6. Erişim adresi: http://oaji.net/articles/2015/490-1440162921.pdf

Baykara, S.T. (2014). OECD ülkelerinde iç denetim. Denetişim Dergisi, 14, 42-58. Erişim adresi: https://dergipark.org.tr/en/pub/denetisim/issue/22467/240303

Chang, Y. T., Chen, H., Cheng, R. K. ve Chi, W. (2019). The impact of internal audit attributes on the effectiveness of internal control over operations and compliance. Journal of Contemporary Accounting \& Economics, 15(1), 1-19. Erişim adresi: https://www.sciencedirect.com/science/article/pii/S1815566918301589

Chen, Y., Eshleman, J. D. ve Soileau, J. S. (2016). Board gender diversity and internal control weaknesses. Advances in Accounting, 33, 11-19. Erişim adresi: https://www.sciencedirect.com/science/article/pii/S0882611015301103

Committee of Sponsoring Organizations. (2013). Internal control integrated framework executive summary. Erişim adresi: https://www.coso.org/Documents/990025P-Executive-Summary-final-may20.pdf

Çevik, O. ve Ağmaz, S. (2019). Türkiye’deki Büyükşehir Belediyelerinin İç Kontrol Sistemlerinin Kamu İç Kontrol Standartlarına Uyum Durumlarının Araştırılması. Mehmet Akif Ersoy Üniversitesi Sosyal Bilimler Enstitüsü Dergisi, 11(27), 78-96. doi:10.20875/makusobed.493346

Doyle, J., Ge, W. ve McVay, S. (2007). Determinants of weaknesses in internal control over financial reporting. Journal of Accounting and Economics, 44(1-2), 193-223. Erişim adresi: https://www.sciencedirect.com/science/article/pii/S0165410106000905

Fourie, H. ve Ackermann, C. (2013). The impact of COSO control components on internal control effectiveness: an internal audit perspective. Journal of Economic and Financial Sciences, 6(2), 495-518. Erişim adresi: https://hdl.handle.net/10520/EJC142871

Graham, L. (2015). Internal control audit and compliance. New Jersey:John Wiley\&Sons,. 
Hazine ve Maliye Bakanlığı. (2009). Kamu iç kontrol standartlarına uyum eylem planı rehberi. Erişim adresi: http://www.malihizmetler.org.tr/dosyalar/ickontrol3.pdf

Hung, D.T. ve Tuan, T.T. (2019). Factor affecting the effectiveness of internal control in joint stock commercial banks in vietnam, Management Science Letters, 9, 1799-1812. Erişim adresi: http://www.growingscience.com/msl/Vol9/msl_2019_158.pdf

Hunziker, S. (2017). Efficiency of internal control: evidence from Swiss non-financial companies. Journal of Management \& Governance, 21(2), 399-433. Erişim adresi: https://link.springer.com/content/pdf/10.1007/s10997-016-9349-1.pdf

Krippendorff, K. (1980). Content analysis: An introduction to its methodology. Sage: London. Erişim Aderesi: https://www.ocac.cl/wp-content/uploads/2015/01/Klaus-Krippendorff-Content-analysis.-Anintroduction-to-its-methodology.pdf

İç Denetim Koordinasyon Kurulu. (2021). 08.02.2021 tarihi itibariyle kamu idarelerindeki iç denetçi kadroları. Erişim adresi: https://www.hmb.gov.tr/kamu-idareleri-ic-denetci-kadrolari

Lartey, P. Y., Kong, Y., Bah, F. B. M., Santosh, R. J. ve Gumah, I. A. (2020). Determinants of internal control compliance in public organizations; using preventive, detective, corrective and directive controls. International Journal of Public Administration,43(8), 711-723. Erişim adresi: https://www.tandfonline.com/doi/pdf/10.1080/01900692.2019.1645689? needAccess=true

Liang, C., Lourie, B. ve Yeung, P. E. (2019). Female rank-and-file accounting employees and internal control quality, Working paper, 1-36. doi:http://dx.doi.org/10.2139/ssrn.3504465

Maliye Bakanlığı Strateji Geliştirme Başkanlığı İç Kontrol Dairesi. (2019). İç kontrol kavramlar sözlüğü. Erişim adresi: $\quad$ https://ms.hmb.gov.tr/uploads/2019/01/\%C4\%B0\%C3\%A7-Kontrol-Kavramlar\%C4\%B1S\%C3\%B6zl\%C3\%BC\%C4\%9F\%C3\%BC-INTOSAI.pdf

Moeller, R. R. (2013). Executive's guide to Coso internal controls: understanding and implementing the new framework. New Jersey:John Wiley\&Sons,.

Oussii, A. A. ve Taktak, N. B. (2018). The impact of internal audit function characteristics on internal control quality. Managerial Auditing Journal, 33(5), 450-469. Erişim adresi: https://www.emerald.com/insight/content/doi/10.1108/MAJ-06-2017-1579/full/pdf?title=the-impactof-internal-audit-function-characteristics-on-internal-control-quality

Rae, K. ve Subramaniam, N. (2008). Quality of internal control procedures antecedents and moderating effect on organisational justice and employee fraud. Managerial Auditing Journal, 23(2), 104-124. Erişim adresi:https://www.emerald.com/insight/content/doi/10.1108/02686900810839820/full/pdf?title=quali ty-of-internal-control-procedures-antecedents-and-moderating-effect-on-organisational-justice-andemployee-fraud

Sayıştay. (2020). Kamuda stratejik yönetim kurumsal risk yönetimi iç kontrol sistemi analiz çalışması. Erişim adresi:https://www.sayistay.gov.tr/tr/Upload/95906369/files/yayinlar/2019\%20Analiz\%20Kitab\%C4\% B1-27_01_2021.pdf. 
Sayıştay. (2020). 2019 yılı kamu idareleri denetim raporları. Erişim adresi: https://www.sayistay.gov.tr/tr/?p=2\&ContentID=1899

Shen, H., Xiong, H., Zheng, S. ve Hou, F. (2021). Chief executive officer (CEO)'s rural origin and internal control quality. Economic Modelling, 95, 441-452. Erişim adresi: https://www.sciencedirect.com/science/article/pii/S0264999319320474

Yılancı, F.M. (2015). İç denetim ve iç kontrol değerleme rehberi. Ankara: Detay Yayıncılık.

Yılmaz, R. (2019). Belediye, il özel idareleri ve 5018 sayılı kanuna tabi olan mahalli idare birliklerinde iç kontrol sistemini kurmanın önemi ve içişleri bakanlığının konuya yaklaşımı. T.C. Hazine ve Maliye Bakanlığı İ̧̧ Kontrol Okuma Listesi, 1-17. Erişim adresi: https://ms.hmb.gov.tr/uploads/2019/06/6853FD1DCB722CE94984A3E4023D4F886CEA7D357696.pdf

$\mathrm{Xu}, \mathrm{X}$. ve Gao, L. (2015). An empirical study on the factors affecting the effectiveness of internal control of listed corporation-based on the perspective of corporate governance. International Journal of Auditing, $12(4)$, 45-53. Erişim adresi: https://aisel.aisnet.org/cgi/viewcontent.cgi?article=1015\&context=whiceb2015 


\section{EK 1}

Stratejik Yönetim, Kurumsal Risk Yönetimi ve İç Kontrol Sistemi Değerlendirme Prosedürleri
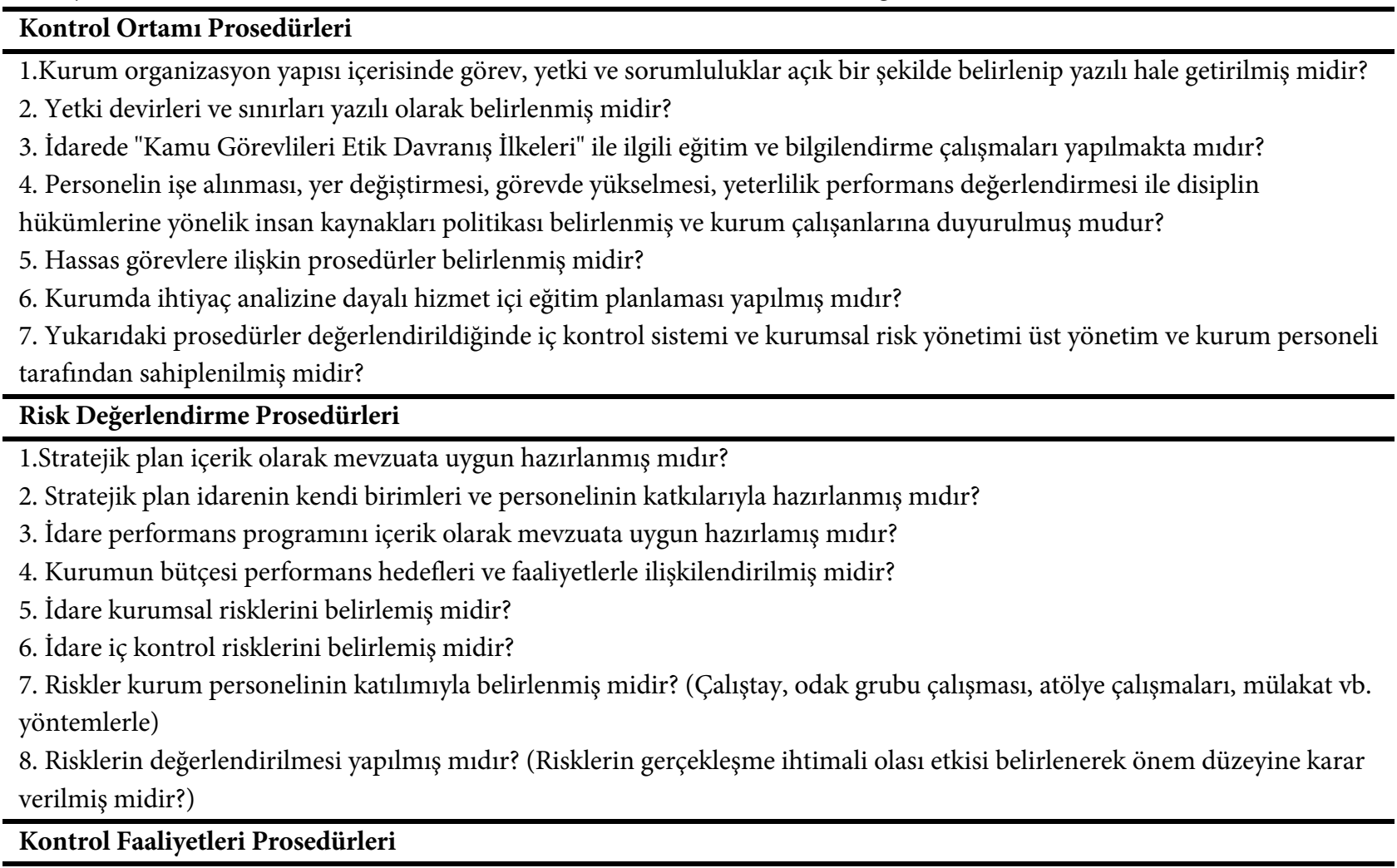

1. İş akış süreçleri belirlenmiş midir?

2. İdare yaptığı görevlendirmelerde görevler ayrılığı ilkesini dikkate almakta mıdır?

3. İdarece belirlenen risklerin kabul edilebilir düzeye indirilmesine yönelik kontrol faaliyetleri belirlenmiş midir?

4. Belirlenen her bir kontrol faaliyetinin uygulanması için sorumlular belirlenmiş midir?

5. Ön mali kontrol sistemi, İç Kontrol ve Ön Mali Kontrole İlişkin Usul ve Esaslara uygun olarak kurulmuş mudur?

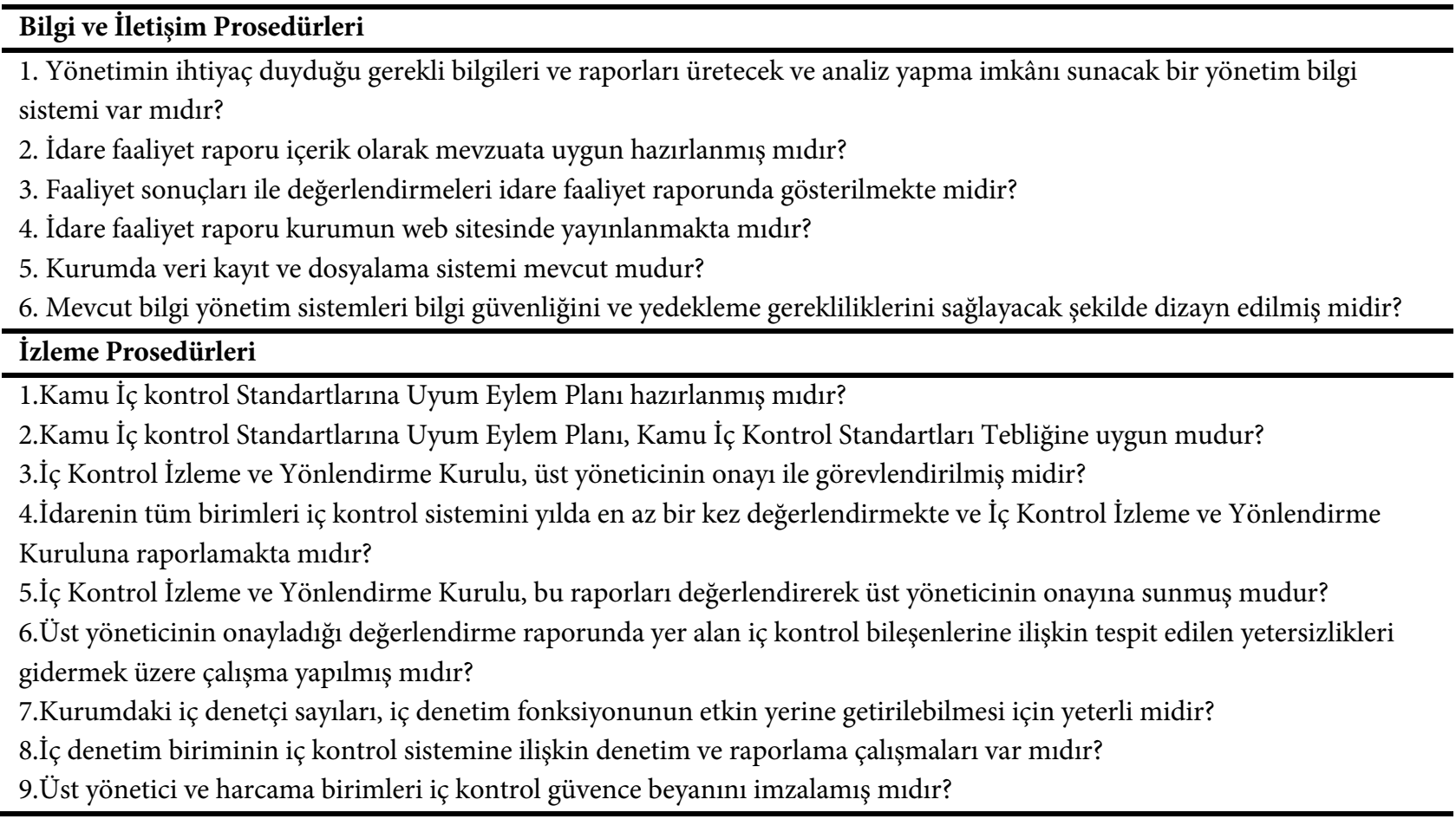
Kaynak: Sayıştay (Kamuda Stratejik Yönetim Kurumsal Risk Yönetimi İç Kontrol Sistemi Analiz Çalışması), 2020, s. 10-11. 
EK 2

Puanlama Anahtarı

\begin{tabular}{cl}
\hline Puan & İfadesi \\
\hline 0 & Hayır, bu konuda bir çalışma mevcut değildir. \\
1 & Bu konuda çalışmalar mevcuttur ancak tamamlanmamıştır \\
2 & Bu konudaki çalışmalar tamamlanmıştır ancak uygulamaya henüz geçilmemiştir. \\
3 & Bu konudaki çalışmalar tamamlanmıs, uygulamaya geçilmiş ancak uygulamada yetersizlikler \\
& mevcuttur. \\
4 & Evet, bu konuda etkin bir uygulama mevcuttur.
\end{tabular}

Kaynak: Sayıştay (Kamuda Stratejik Yönetim Kurumsal Risk Yönetimi İç Kontrol Sistemi Analiz Çalışması), 2020, s. 10-11.

\section{Extended Abstract}

\section{Purpose}

The aim of this study is to determine the factors affecting the efficiency of the internal control systems of metropolitan municipalities.

\section{Design and Methodology}

In this study, content analysis was performed first and ranking was made by creating an internal control performance score from the highest achievement level to the lowest achievement level for each municipality. Subsequently, the factors determining the effectiveness of the internal control system were determined by correlation analysis.

\section{Findings}

There is a statistically positive or negative correlation with other variables in the literature and used in the correlation analysis (Number of Internal Auditor Staff of the Municipality, Number of Internal Audit Reports, Realized Budget Expenditures and Revenues in 2019, Budget Balance, Population, Geographical Region, Education Level and Gender of the President) relationship could not be detected. A statistically significant negative relationship was found only between political ideology and internal control performance. As a result of the analysis, it has been determined that the level of success achieved by scoring the "Internal Control System Evaluation Procedures" in three metropolitan municipalities where the mayor is appointed as a trustee is partially lower compared to other metropolitan municipalities. Among the factors used in the study, a significant result was found only between the political ideology of the mayor and the effectiveness of the internal control system.

\section{Research Limitations}

The study has two main limitations. The first constraint is the number of data. Since only metropolitan municipalities were included in the study in order to ensure homogeneity, the data of 30 metropolitan municipalities were used. Another important limitation of the study is that the internal control system has not yet been implemented in public administrations and there is no standard framework for the evaluation of the internal control system. 


\section{Implications (Theoretical, Practical and Social)}

It is foreseen that the number of data will be increased and the results to be obtained in studies to be conducted in different public administrations will be more meaningful.

\section{Originality/Value}

In the study, the scoring was done according to the application/non-implementation status of the procedures with content analysis, which is a research method in order to reach objective and systematic information about the internal control system of the municipalities. Considering the scale in the analysis study conducted by the TCA in 2020 and using a similar method, the "Internal Control System Evaluation Procedures" of metropolitan municipalities were scored in order to quantify the verbal data in the audit reports. As a result of the scoring, it is aimed to obtain scores for the effectiveness/ineffectiveness of the internal control systems of each municipality. Although the study is a study aimed at describing the current situation, secondary data were obtained by evaluating the primary data (performance audit reports of metropolitan municipalities) with content analysis. It was predicted that another researcher would obtain a result close to a similar ranking when he scored the information in the audit reports evaluated within the scope of the research.

Araştırmacı Katkısı: Durdane KÜÇÜKAYCAN (\%50), Şafak AĞDENİ (\%50). 